\title{
Seismic LAB or LID? The Baltic Shield case
}

\author{
M. Grad ${ }^{1}$, T. Tiira ${ }^{2}$, S. Olsson ${ }^{3,{ }^{*}}$, and K. Komminaho ${ }^{2}$ \\ ${ }^{1}$ Institute of Geophysics, Faculty of Physics, University of Warsaw, Pasteura 7, 02-093 \\ Warsaw, Poland \\ ${ }^{2}$ Institute of Seismology, University of Helsinki, P.O. Box 68, 00014, Helsinki, Finland \\ ${ }^{3}$ Department of Earth Sciences, Uppsala University, Villavägen 16, 75234 Uppsala, Sweden \\ "now at: Department of Mineral Resources, Geological Survey of Sweden, P.O. Box 670, \\ 75128 Uppsala, Sweden
}

Received: 2 May 2013 - Accepted: 3 May 2013 - Published: 23 May 2013

Correspondence to: M. Grad (mgrad@ mimuw.edu.pl)

Published by Copernicus Publications on behalf of the European Geosciences Union.

\section{Seismic LAB or LID? The Baltic Shield case}

\section{Grad et al.}

\section{Title Page}

\section{Full Screen / Esc}

Printer-friendly Version

Interactive Discussion 


\section{Abstract}

The problem of the asthenosphere for old Precambrian cratons, including East European Craton and its part - the Baltic Shield, is still discussed. To study the seismic lithosphere-asthenosphere boundary (LAB) beneath the Baltic Shield we used records 5 of 9 local events with magnitudes in the range 2.7-5.9. The relatively big number of seismic stations in the Baltic Shield with a station spacing of 30-100 km permits for relatively dense recordings, and is sufficient in lithospheric scale. For modelling of the lower lithosphere and asthenosphere, the original data were corrected for topography and the Moho depth for each event and each station location, using a reference model predicted by the iasp91 model, which clearly indicates that lithospheric $P$ and $S$ velocities beneath the Baltic Shield are higher than in the global iasp91 model. For two northern events at Spitsbergen and Novaya Zemlya we observe a low velocity layer, 60-70 km thick asthenosphere, and the LAB beneath Barents Sea was found at depth of about $200 \mathrm{~km}$. Sections for other events show continous first arrivals of $P$ waves with no evidence for "shadow zone" in the whole range of registration, which could be interpreted as absence of asthenosphere beneath the central part of the Baltic Shield, or that LAB in this area occurs deeper $(>200 \mathrm{~km})$. The relatively thin low velocity layer found beneath southern Sweden, $15 \mathrm{~km}$ below the Moho, could be interpreted as small scale lithospheric inhomogeneities, rather than asthenosphere. Differentiation of the lid velocity beneath the Baltic Shield could be interpreted as regional inhomogeneity. It could also be interpreted as anisotropy of the Baltic Shield lithosphere, with fast velocity close to the east-west direction, and slow velocity close to the south-north direction.

\section{Introduction}

25 In the new global plate tectonics the crucial elements are moving lithospheric plates. The lithosphere (from the Greek: $\lambda i \theta o s$ - rocky, rigid) is understood as an outer shell
SED

5, 699-736, 2013

\section{Seismic LAB or LID? \\ The Baltic Shield case}

M. Grad et al.

\section{Title Page}

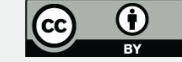


of the Earth, which consists of the crust and a certain part of the upper mantle. Rigid lithosphere, sometimes called the "lid", is underlain by ductile asthenosphere (from the Greek: $\alpha i \sigma \theta \varepsilon v \omega$ s - weak). Petrological studies of xenoliths and thermal modelling based on heat flow measurements allow to determine temperature gradients in the 5 lower lithosphere, give some image of lithosphere composition and provide important suggestions about the depth of the wide transitional zone between lithosphere and asthenosphere named as LAB (lithosphere-asthenosphere boundary). The LAB is not a sharp discontinuity, but rather a gradual and wide transition zone (see e.g. Meissner, 1986). From the point of view of elastic properties and seismic velocities, the 10 asthenosphere could be identified as a low-velocity channel in the 50-200 km depth range in Gutenberg's global model of the Earth (Gutenberg, 1959). Later, low seismic velocities in the upper mantle were found also in regional scale beneath continents and oceans (e.g. Anderson and Toksöz, 1963; Johnson, 1967; Schubert et al., 1976; Grad, 1988). The LAB depth strongly depends on temperature: thicker lithosphere up 15 to about $200 \mathrm{~km}$ is clearly observed under "cold" Precambrian shields and platforms, while the thinnest lithosphere of $50-100 \mathrm{~km}$ is found under "hot" oceans and oceanic and continental rifts. Recently the lithosphere-asthenosphere boundary depth and low velocities are effectively estimated from velocity variations of global and regional tomography models, group velocity of long period $(T \sim 100 \mathrm{~s})$ surface waves and $S$ wave 20 receiver functions (e.g. Bruneton et al., 2004; Gregersen et al., 2006; Li et al., 2007; Pasyanos, 2010; Wilde-Piórko et al., 2010). The LAB may also correlate with a downward extinction of seismic anisotropy or a change in the anisotropy direction (e.g. Eaton et al., 2009; Plomerová and Babuška, 2010). The asthenosphere could be also identified with a low-viscosity zone and low value of the quality factor $Q_{S}$ (e.g. Stacey, 25 1969). Characteristic for asthenosphere is low seismic activity or even total lack of earthquakes. The electrical LAB is marked by a significant reduction in electrical resistivity, where resistive lithosphere is overlying a highly conductive asthenosphere. The electrical asthenosphere, identified as a high conductive layer (low resistivity layer) in the upper mantle often coincides with a seismic low-velocity zone (e.g. Eaton et al.,

\section{SED}

$5,699-736,2013$

\section{Seismic LAB or LID? \\ The Baltic Shield case}

M. Grad et al.

Title Page

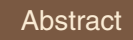

Introduction

Conclusions

References

Tables

Figures

14

$\rightarrow 1$

4

Back

Close 
2009; Martinec and Wolf, 2005; Korja, 2007). Last but not least is thermal lithosphere. The use of the borehole heat flow measurements allows calculation of the lithospheric geotherms and estimation of the thermal lithosphere thickness, defined as the depth where the continental geotherms intersect the $1300^{\circ} \mathrm{C}$ mantle adiabat (e.g. Artemieva, 5 2007; Artemieva and Mooney, 2001).

Because mostly of their temperature nature the both boundaries of the asthenosphere: upper - LAB, and lower - bottom of the asthenosphere, are not first order seismic discontinuities, but rather gradient zones. Because of this, a large contrast of elastic parameters is not expected and we do not expect strong enough reflected and o converted phases - which is not good news for seismic reflection and receiver function techniques. So, as the most promising for the determination of the seismic LAB depth remain the methods of surface waves, seismic tomography, and searching for "shadow zones" of $\mathrm{P}$ and $\mathrm{S}$ body waves. Shadow zones are expected at epicentral distances about $1500-2000 \mathrm{~km}$. For this, local seismic events of relatively big magnitudes permit15 ting good quality records at long distances from the source could be used (Fig. 1).

\section{The Baltic Shield and previous seismic investigations of the lithosphere and LAB}

The East European Craton (EEC) is the coherent Precambrian part of Europe, mainly of Archaean and Palaeoproterozoic age, assembled in the Late Palaeoproterozoic 20 zoic terranes of the Trans-European suture zone (TESZ) which extends from the British
Isles to the Black Sea region. The northeastern part of the European continent occupies the Baltic (also Fennoscandian) Shield with the Precambrian bedrock exposed on the Earth's surface (Figs. 1 and 2).

25 The typical three-layer crust of the Baltic Shield has a thickness in the range of 42$60 \mathrm{~km}$, and attains its maximum thickness in Central Finland. The $P$ wave velocities in the upper crust are $6.0-6.4 \mathrm{~km} \mathrm{~s}^{-1}$, in the middle crust $6.6-6.9 \mathrm{~km} \mathrm{~s}^{-1}$ and in the
SED

$5,699-736,2013$

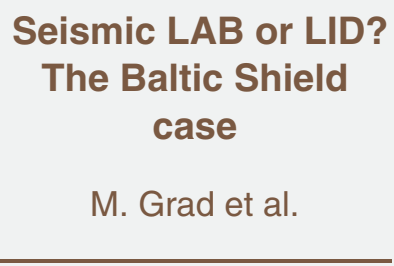

Title Page

\section{Full Screen / Esc}

Printer-friendly Version

Interactive Discussion 
lower crust $>7.0 \mathrm{kms}^{-1}$. The thickness of the upper and middle crust is in the range of $32-42 \mathrm{~km}$. The thickness of the lowermost high-velocity crustal layer is in the range of $4-24 \mathrm{~km}$. The $P$ wave velocity in the uppermost mantle is $7.9-8.2 \mathrm{~km} \mathrm{~s}^{-1}$. The ratio of $P$ wave velocity to $S$ wave velocity varies typically from 1.67-1.70 in the upper 5 crust to 1.77-1.80 in the lower crust. In the upper mantle the ratio is about 1.73 (e.g. Guggisberg, 1986; Grad and Luosto, 1987; Luosto, 1997; Hyvonen et al., 2007).

Similar to other old Precambrian cratons, features of the asthenosphere beneath the Baltic Shield are still discussed. First determinations of the lithospheric thickness beneath the Baltic Shield were obtained from analyses of fundamental-mode and higherorder Rayleigh surface waves. The dispersion of higher-mode data have been interpreted by Nolet (1977) to distinguish the thick lithosphere of the Baltic Shield from the thinner Western European lithosphere (see also Zielhuis and Nolet, 1994). Cara et al. (1980) using higher modes found no need for a low-velocity zone in the mantle beneath northern Eurasia. They also argue that a nearly constant $4.5-4.6 \mathrm{~km} \mathrm{~s}^{-1}$ $15 \mathrm{~S}$ wave velocity is required in the uppermost $200 \mathrm{~km}$. Using Rayleigh-wave dispersion data for the Fennoscandian region, Calcagnile (1982) found lid thicknesses up to around $135 \mathrm{~km}$ in the Bothnia - north-central Finland area with weak, if any, shear velocity contrast to the underlying layer. The surrounding areas are characterized by lid thicknesses up to around $75 \mathrm{~km}$ only. A stronger low-velocity zone with lid contrast $20 \quad 0.25 / 0.45 \mathrm{~km} \mathrm{~s}^{-1}$ may be found in the Caledonian and the Baltic Sea area (Calcagnile, 1982). An updated map of the lithosphere-asthenosphere system in Europe (Panza, 1985; Calcagnile and Panza, 1987) shows much larger lithospheric thickness of the Baltic Shield, in the range $110-170 \mathrm{~km}$, increasing to $>190 \mathrm{~km}$ in its central part. The Baltic Shield model obtained later by Dost (1990) shows an absence of the low-velocity 25 layer, while density seems to be lower in 200-350 km depth.

The deep structure of the lower lithosphere and asthenosphere can also be investigated from studies of $P$ waves. From the explosive source refraction profile FENNOLORA Guggisberg (1986) interpreted several deep low-velocity channels (of about $5 \%$ decrease in $\mathrm{P}$ wave velocity in a few tens $\mathrm{km}$ thick layers) in the lower lithosphere,
SED

5, 699-736, 2013

\section{Seismic LAB or LID? \\ The Baltic Shield case}

M. Grad et al.

Title Page 
with the bottom of the lithosphere at about $200 \mathrm{~km}$ depth marked by a velocity change of a couple of per cent. Regional 1-D $S$ wave velocity models obtained for the central part of the Baltic Shield from the SVEKALAPKO array (Kozlovskaya et al., 2008) show that velocities beneath craton are significantly bigger (about $4 \%$ down to a depth 5 of $250 \mathrm{~km}$ ) compared to standard model iasp91 (Kennett and Engdahl, 1991). On the other hand lowering of the velocity with depth is not visible (Kozlovskaya et al., 2008). This fact could be interpreted as absence of asthenosphere, or that LAB in this area occurs deeper. Plomerová and Babuška (2010) define the LAB as a boundary between a fossil anisotropy in the lithospheric mantle and an underlying seismic anisotropy re10 lated to present-day flow in the asthenosphere. The LAB topography is more distinct beneath the Phanerozoic part of Europe than beneath its Precambrian part. Beneath central Fennoscandia the LAB deepens down to $\sim 220 \mathrm{~km}$ (Plomerová and Babuška, 2010).

\section{Seismic data for the Baltic Shield}

15 The area of the Central and Northern Europe is a region characterized by weak to moderate seismicity (e.g. Slunga, 1991; Ahjos and Uski, 1992). The map in Fig. 1 shows location of 2698 events in the Baltic Shield and surroundings, recorded from January 2008 to September 2011. Most of these events were classified as earthquakes. Events recorded at less than three stations, as well as those which were explosions from known sites, were omitted from the data set. Mining-induced seismic events (e.g. rock bursts, mine collapses) were also excluded from the cataloque. However, it is likely that man-made events still exist in the data, especially among low magnitude events (Uski and Raime, 2010).

It is seen from Fig. 1 that seismic events are concentrated in few distinct areas. In 25 the north $\left(18-20^{\circ} \mathrm{E}, 77-78^{\circ} \mathrm{N}\right)$ a group of events is concentrated in the southern part of Spitsbergen, within a continental crust of the Barents Sea block (see also Figs. 2 and 3). West of $10^{\circ} \mathrm{E}$ and north of $73^{\circ} \mathrm{N}$, a linear group of epicenters is related to the

SED

$5,699-736,2013$

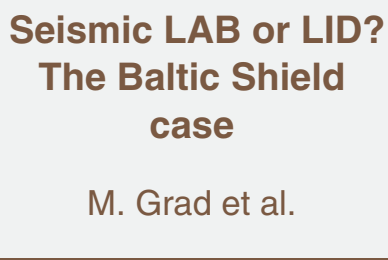

Title Page

Abstract

Introduction

Conclusions

Tables

References

Figures

14

$\Delta$

4

Back

Full Screen / Esc

Printer-friendly Version

Interactive Discussion
$>$

Close

作

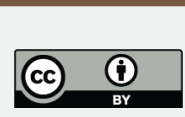


Knipovich Ridge and Mohns Ridge segments of the Mid-Atlantic Ridge. Events south of this group are related with continent-ocean transition (COT), transition between oceanic crust of the Atlantic and continental crust of the Barents Sea. The coastal area of Scandinavia is characterized by moderate seismicity of the Caledonides. In the south 5 of the study area $\left(6-8^{\circ} \mathrm{E}, 50-52^{\circ} \mathrm{N}\right)$, a group of events is related with seismic activity of young continental rift - Rhein Graben. Events scattering around $16^{\circ} \mathrm{E}$ and $52^{\circ} \mathrm{N}$ are related to the area of cupper mines activity in SW Poland (Lubin area). There are both natural and induced earthquakes in this area. Next to the east, the area around $19^{\circ} \mathrm{E}$ and $50^{\circ} \mathrm{N}$ is related to the seismicity of coal mines activity in Silesia (Draber et al., 10 2002). The Baltic Shield in general is a stable intraplate region characterized by weak to moderate seismicity, with event magnitudes ML rarely exceeding 4.0. The majority of earthquakes occur within the Kuusamo-Kandalaksha region in north-eastern Finland and adjacent Russia $\left(28-35^{\circ} \mathrm{E}, 65-68^{\circ} \mathrm{N}\right)$, and along a broad $\mathrm{N}-\mathrm{S}$ oriented belt running parallel to an ancient plate boundary, from the Bothnian Bay to northern Norway (from $1518^{\circ} \mathrm{E}, 63^{\circ} \mathrm{N}$ to $25^{\circ} \mathrm{E}, 70^{\circ} \mathrm{N}$ ) (Ahjos and Uski, 1992). Events in the Kuusamo area are the most frequently recorded natural earthquakes in Finland. However they are rather weak, and most of them are detected only because there is a local seismic array (Fig. 2) in this area. In the south of the Baltic Shield, an area of rare seismicity in Scania (11$14^{\circ} \mathrm{E}, 55-57^{\circ} \mathrm{N}$ ) has had some relatively strong (with magnitude up to 5 ) events. In the 20 Fennoscandian area 80-90\% of all earthquakes occur in the upper $20 \mathrm{~km}$ of the Earth's crust (Slunga, 1991; Ahjos and Uski, 1992). Earthquakes in the depths of $40 \mathrm{~km}$ and deeper are rare. Some well-determined events in northern Sweden have been located close to the crust-mantle boundary (Arvidsson and Kulhanek, 1994; Arvidsson, 1996). These observations suggest that the Archean lower crust may be seismically active and involved in brittle deformation (Uski et al., 2012).

To study of the lithosphere-asthenosphere system of the Fennoscandia we need relatively effective sources (earthquakes or quarry blasts) generating seismic waves which could be recorded up to a distance of at least $2000 \mathrm{~km}$. In the first step of event selection we chose the strongest events that occurred within last years. We have

SED

$5,699-736,2013$

\section{Seismic LAB or LID? \\ The Baltic Shield case}

M. Grad et al.

\section{Title Page}

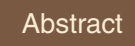

Introduction

Conclusions

References

Tables

Figures

14

$>1$

4

Back

$>$

Close

Full Screen / Esc

Printer-friendly Version

Interactive Discussion 
chosen to use fairly recent events since this will enable us to use data recorded by stations of the National Swedish Seismic Network (SNSN), a dense regional seismic network of broadband stations allowing good quality records of local events (e.g. Olsson, 2007). The number of SNSN stations has grown rapidly in the last decade and 5 today has a good coverage of most of Sweden. Because of the size of the Baltic Shield (about $1500 \mathrm{~km}$ in diameter) we limited out data set to events from the outskirts of the Baltic Shield in order to obtain large enough station to event distance range. The chosen 9 events are listed in Table 1 and shown in Fig. 2 (event no. 8 at Novaya Zemlya is located outside of the map frame). The magnitudes of events are in the range 2.7-5.9.

10 Exception is the small event no. 10 in Western Finland of magnitude 1.1 which occurred nearly at the same time as event no. 9 from Rhine Graben (both events were recorded simultaneously). In Fig. 2 earthquakes are marked by black stars with numbers and seismic stations providing data are marked by black dots.

\section{Average velocities, reference model and time corrections}

15 The relatively big number of seismic stations in the Baltic Shield permits for relatively dense recordings of events, with a distance between stations of $30-100 \mathrm{~km}$. This spacing is sufficient in lithospheric scale studies where the penetration depth of body waves is a few hundreds of $\mathrm{km}$ and the wave length is of the order of a few $\mathrm{km}$. Recording stations are not linearly aligned which would permit for easy 2-D interpretation of the

structure along profile, but scattered in a wide corridor of a few hundreds $\mathrm{km}$ width. This means that two stations at similar epicentral distance may lie in locations with significantly different altitude and Moho depth. For modelling the lower lithosphere and asthenosphere along profiles, the original data needs to be time corrected for topography and the Moho depth for each event and each station location. Topography for seismic station locations is changing from close to sea level up to $630 \mathrm{~m}$ (see Fig. 2).

Differences in the Moho depth in the study area are significantly larger. As seen from Fig. 3 the Moho depth in the Baltic Shield is changing in range of $30-60 \mathrm{~km}$

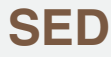

$5,699-736,2013$

\section{Seismic LAB or LID? \\ The Baltic Shield case}

M. Grad et al.

\section{Title Page}


(Grad et al., 2009). An average Moho depth was calculated for the area within the yellow frame shown in Fig. 3 using data from the digital Moho depth map by Grad et al. (2009). The average depth is $45.7 \mathrm{~km}$, and in reference model $46 \mathrm{~km}$ depth was used. $P$ wave velocities in the reference model were compiled from seismic studies in 5 the area. In Fig. 3 the analysed profiles are shown by white lines (Hirschleber et al., 1975; Lund, 1979; Guggisberg, 1986; Luosto, 1986; Grad and Luosto, 1987; Luosto et al., 1989, 1990, 1994; Grad et al., 1991; FENNIA Working Group, 1998; Uski et al., 2012; Tiira et al., 2013) and places of sampled velocities are shown by white dots. All velocity-depth relations were sampled at $1 \mathrm{~km}$ depth intervals. The velocity values 10 were weighted according to reliability of the models. The highest weight was given to data from modern refraction and wide-angle reflection profiles with a dense system of observations and good reciprocal coverage (e.g. SVEKA, BALTIC, POLAR). Velocity in the crust and uppermost mantle were directly extracted from 2-D numerical models with a spacing of $60 \mathrm{~km}$ along profiles. Only parts of models sufficiently sampled by rays were taken to velocity-depth analysis. For older profiles with a sparse system of observations published 1-D models were adopted (e.g. Blue Road, FENNOLORA, Sylen-Porvoo).

$P$ wave velocities in the crust and uppermost mantle of the Baltic Shield were sampled in 67 locations (white dots in Fig. 3). Comparison with location of seismic stations 20 (Fig. 2) shows a good coverage for the whole area of the Baltic Shield. In total 4269 values of velocity were used for determination of average velocity-depth relations in the crust and uppermost mantle. The data were fitted by linear functions:

$V(z)=5.97+0.0257 z$ for the crust

and

$V(z)=7.71+0.0091 z$ for the uppermost mantle

where $V$ is $\mathrm{P}$ wave velocity in $\mathrm{km} \mathrm{s}^{-1}$ and $z$ is depth in $\mathrm{km}$. The data distribution is shown in gray scale in Fig. 4a. Apart from fitted relations (1) and (2) the reference 707
SED

5, 699-736, 2013

\section{Seismic LAB or LID? \\ The Baltic Shield \\ case}

M. Grad et al.

Title Page

\section{Full Screen / Esc}

Printer-friendly Version

Interactive Discussion 
model is shown by thick black dotted line (Fig. 4a). The model has a $46 \mathrm{~km}$ thick crust with velocities increasing from 5.97 at the Earth's surface to $7.24 \mathrm{~km} \mathrm{~s}^{-1}$ at the $46 \mathrm{~km}$ depth. The velocity below the Moho at $46 \mathrm{~km}$ depth is $8.13 \mathrm{~km} \mathrm{~s}^{-1}$.

Traveltimes for reference model with $46 \mathrm{~km}$ Moho depth are shown by the black line 5 in Fig. 4b. For comparison two traveltime curves for shallower Moho (34 km depth, blue line) and deeper Moho (58 km depth, red line) are shown. The differences of time are about $\pm 2 \mathrm{~s}$ at distance $300-500 \mathrm{~km}$, decreasing to about $\pm 1 \mathrm{~s}$ at distance 1000 $1500 \mathrm{~km}$. Traveltimes were calculated with $1 \mathrm{~km}$ interval for the Moho depths from 34 to $58 \mathrm{~km}$. The time corrections were calculated using interpolation for both distances 10 and Moho depths below event and station. The final time corrections included also correction for topography. An example of the application of time corrections is shown in Fig. 5. The map in Fig. 5a shows the location of event no. 3 (Lubin; marked by black star) and seismic stations (black dots) with their numbers. Corresponding sections with corrections and without corrections are shown in Fig. 5b and c, respectively. Red dots are picks of first arrivals (the same picks are shown in both sections). Red lines are traveltimes and gray bands show scattering of the data. Application of time corrections improves correlation. The scattering of first arrivals is about $1 \mathrm{~s}$ for the section with time corrections (Fig. 5b), and about $2 s$ for the section without corrections (Fig. 5c). The histogram in Fig. 5 d shows a distribution of 604 total time corrections. About $93 \%$ of the corrections are in the range from $-0.1 \mathrm{~s}$ to $0.8 \mathrm{~s}$, with maximum for $0.2-0.5 \mathrm{~s}$ interval (282 corrections). Such a processing was applied for all sections in this paper, which permits us to use a reference crustal model, without topography ( 0 a.s.l.) and with a reference Moho at $46 \mathrm{~km}$ depth to model our data. After applying the corrections all sections correspond to Moho depth of $46 \mathrm{~km}$ and stations at sea level.

\section{Searching for asthenosphere beneath the Baltic Shield}

To study the lithosphere-asthenosphere system of the Baltic Shield we chose 9 events (Table 1, Fig. 2) from outskirts of shield. For all record sections time corrections were
SED

$5,699-736,2013$

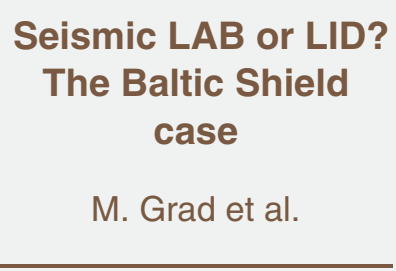

Title Page

Abstract

Introduction

Conclusions

References

Tables

Figures

14

$\rightarrow 1$

4

Back

Close

Full Screen / Esc

Printer-friendly Version

Interactive Discussion 
applied as described in the previous section. Poor quality and noisy seismograms were removed from the sections. Some seismograms were also omitted to avoid crowding of seismograms from stations with similar epicentral distances. All record sections were normalized, filtered, and drawn with reduction velocity $8 \mathrm{~km} \mathrm{~s}^{-1}$ (in some cases with 5 reduction velocity $4.5 \mathrm{~km} \mathrm{~s}^{-1}$ for sections of $S$ waves).

Modelling for all sections in this paper was done using the ray tracing technique and software SEIS83 (Červenỳ and Pšenčík, 1984). As a reference crustal model for $P$ wave velocity we used the model described in the previous section. Crustal $S$ wave velocities were recalculated from $P$ velocities using the relation $V p / V s=1.67$ in the 10 uppermost crystalline basement and $\mathrm{Vp} / \mathrm{Vs}=1.77$ in the lower crust (see e.g. Grad and Luosto, 1987; Bogdanova et al., 2006; Uski et al., 2012). The models of the mantle structure were derived by trial-and-error forward modelling. Traveltimes and synthetic seismograms were calculated for 1-D models with Earth-flattening transformation for waves from a point source (Hill, 1972).

15 Two examples of record sections for event no. 3 (Lubin) and for event no. 6 (Kola) are shown in Figs. 6 and 7. Apart of the full wave fields of P, S and surface waves (Figs. $6 a$ and $7 a$ ) enlarged parts of sections are shown for $S$ (Figs. $6 b$ and $7 b$ ) and $P$ waves (Figs. 6c and 7c). Red dots are picked first arrivals for $P$ and $S$ waves, and red lines are first arrivals of $\mathrm{P}$ and $\mathrm{S}$ waves calculated for the iasp91 model (Kennett and Engdahl, 1991). Although the crustal thickness in iasp91 model is only $35 \mathrm{~km}$ (in comparison to $46 \mathrm{~km}$ for the Baltic Shield), observed $\mathrm{P}$ and $\mathrm{S}$ arrivals are both significantly earlier than predicted by the iasp91 model - at distance $1700 \mathrm{~km}$ about 3-4 s for $P$ waves and about $6-8 \mathrm{~s}$ for $S$ waves. This is a clear indication that lithospheric $P$ and $S$ velocities beneath the Baltic Shield are higher than those in the iasp91 model. Also the observed continuation of the first arrivals up to $1700-2000 \mathrm{~km}$ distance could be interpreted as a lack of a "shadow zone". High lithospheric velocities for the East European Craton using $\mathrm{Pn}$ and $\mathrm{Sn}$ waves recorded at teleseismic distances were described nearly fifty years ago by Båth (1966).

\section{SED}

$5,699-736,2013$

\section{Seismic LAB or LID? \\ The Baltic Shield case}

M. Grad et al.

\section{Title Page}

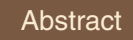

Introduction

Conclusions

References

Tables

Figures

14

$\rightarrow$

4

Back

Close 
Sections with records up to $2200-3000 \mathrm{~km}$ distance are shown in Figs. 8 and 9. For event no. 8 (Novaya Zemlya) good quality first arrivals of $P$ waves are recorded in the distance range $1300-3000 \mathrm{~km}$. At an epicentral distance of about $1800 \mathrm{~km}$ a clear "shadow zone" is visible (marked in Fig. 8 by arrow). Corresponding rays are shown 5 in ray diagram: red rays traveling in the lithosphere and navy blue rays reflected from the bottom of the asthenosphere and mantle including " 410 " and "660" km boundaries. Also shown in Fig. 8 is a comparison between the 1-D velocity model for this event and the iasp91 model. An interesting observation is related with frequency of first arrivals. Lithospheric phases have significantly higher frequencies than deeper phases. This 10 change occurs at relatively short epicentral distance - compare them at $1900 \mathrm{~km}$ and $2100 \mathrm{~km}$. One explanation could be stronger attenuation of high frequency content of a pulse traveling trough the asthenosphere. In such a case the asthenosphere should be characterized by a lower value of the quality factor $\mathrm{Qp}$. The next figure shows next two sections (Fig. 9). For event no. 2 (Spitsbergen) good quality $P$ waves are recorded 15 in the distance range $800-2400 \mathrm{~km}$. First arrivals are far away from explosive character - monotonic increase of amplitude to maximum of the seismic moment takes about $5 \mathrm{~s}$ (Pirli et al., 2010). In such a case correlation of further arrivals is practically impossible. This is illustrated in Fig. 9b showing synthetic seismograms calculated for an extremely long source pulse. However, because of the big size of event $(M=5.9)$ correlation of first arrivals was unquestionable and was done through a manual process on a computer screen, using software ZPLOT (Zelt 1994) allowing flexible use of scaling, zooming, filtering, and reduction velocity. For the two northern events at Spitsbergen and Novaya Zemlya we observe low velocity layer - asthenosphere. The LAB beneath Barents Sea was found there at depth of about $200 \mathrm{~km}(198 \mathrm{~km}$ and $201 \mathrm{~km}$ for event no. 2 at Spitsbergen and for event no. 8 at Novaya Zemlya, respectively).

Section for event no. 7 (Bełchatów) shows continuous first arrivals of $P$ waves with no evidence for a "shadow zone" in the whole range of registration (Fig. 9c). A lack of "shadow zone" could be interpreted as a lack of asthenosphere beneath central part of the Baltic Shield, or that LAB in this area occurs deeper (> $200 \mathrm{~km})$.

\section{SED}

$5,699-736,2013$

\section{Seismic LAB or LID? \\ The Baltic Shield case}

M. Grad et al.

Title Page

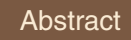

Introduction

Conclusions

References

Tables

Figures

14

$\rightarrow$

4

Back

Close 


\section{Models of the lower lithosphere structure}

Other data we collected do not show evidence for the existence of asthenosphere beneath the Baltic Shield. However, they contain information about the lower lithosphere inhomogeneities which could be deduced from $P$ and $S$ waves (Figs. 10 to 13).

The sections shown in Fig. 10 need more explanation. About $4.5 \mathrm{~min}$ after event no. 9 (Rhein Graben, $M=4.0$ ) at a distance of about $1800 \mathrm{~km}$ towards the norheast, a smaller earthquake occurred in Western Finland (event no. 10, $M=1.1$; see Table 1). The section in Fig. 10a shows both events, recorded simultaneously. Phases attributed to the small event in Finland are here highlighted in yellow (recorded in epicentral distance 1500-2200 km of event no. 9). In Figs. 10b and c the location of this event and record section are shown. $\mathrm{Pg}, \mathrm{Pn}, \mathrm{Sg}$ and $\mathrm{Sn}$ waves calculated for the reference model of the Baltic Shield quite well fit observations. For event no. 9 (Fig. 10a) strong $\mathrm{P}$ and $\mathrm{S}$ waves are recorded up to $1500 \mathrm{~km}$ distance. However, in the distance range $1600-2300 \mathrm{~km}$ the strong $P$ waves have no corresponding strong $S$ waves. This fact 15 is difficult to interpret as lowering of $S$ wave velocity ( $S$ wave asthenosphere). The explanation could be lower quality factor for $S$ waves ("Qs asthenosphere"?).

Lower lithospheric inhomogeneities were interpreted beneath southern Sweden using data for event no. 1 (Skagerak). At a distance of around $600 \mathrm{~km}$ a small break in the continuity of the first arrivals of $P$ waves is observed (Fig. 11). This can be explained by a model with a $16 \mathrm{~km}$ thick LVL $15 \mathrm{~km}$ below the Moho with a $P$ wave velocity drop of $-0.33 \mathrm{~km} \mathrm{~s}^{-1}$. Such a velocity contrast is sufficient to explain the strong amplitudes seen in the distance range $1600-1800 \mathrm{~km}$, as multireflections within the LVL. Red lines in Fig. 11 show first arrivals ( $P n$ and $P$ ), reflection from the bottom of LVL (1) and traveltimes of five multiples in LVL (2)-(6). In synthetic seismograms reflection from multiples practically invisible. We do not interpret the LVL as asthenosphere but as an inhomogeneity in the lower lithosphere.

SED

$5,699-736,2013$

\section{Seismic LAB or LID? \\ The Baltic Shield case}

M. Grad et al.

Title Page

\section{Full Screen / Esc}

Printer-friendly Version

Interactive Discussion 
The next record section (Fig. 12a) illustrates a differentiation of the upper mantle velocities observed for the event no. 4 (Varangerfjord). Although time corrections have been applied, considerable scattering of first arrivals is observed, particularly in the distance interval $200-600 \mathrm{~km}$. Late arrivals are marked in green and corresponding 5 stations are also marked in green in neighboring map (Fig. 12b). Low velocities in the lower lithosphere coincide with the northern part of the Baltic Shield and the Caledonides, and "normal velocities" with the area towards the south (red dots). Even more scattering of first arrivals, up to about $3 \mathrm{~s}$ at about $800 \mathrm{~km}$ distance, is observed for event no. 5 (Scania) shown in Fig. 13. In this case first arrival picks were split into three 10 groups: normal arrivals to the north (red dots), faster to the northeast (light blue dots), and the fastest to the east (navy blue dots).

In the last two sections for event no. 4 (Varangerfjord) and for event no. 5 (Scania) thick gray bar highlights far distance $\mathrm{Pg}$ waves recorded up to about $700 \mathrm{~km}$ distance (Figs. 12 and 13). It means, qualitatively, that attenuation of $P$ waves in the Baltic Shield crust is relatively low. Beneath the SVEKA profile in Finland (Grad and Luosto, 1994) Qp-factor in the uppermost $1 \mathrm{~km}$ is $50-80$ only, but in the crystalline crust it reach values of $500-800$, which means that attenuation in the crust is extremely low.

The records in the last two sections (Figs. 12 and 13) reach distance up to about $1700 \mathrm{~km}$, too short to reach LAB in central part of the Baltic Shield, where it is at depth deeper than $200 \mathrm{~km}$. On the other hand both events, located in the north and in the south of the shield, give valuable information about the lower lithosphere - lid. Based on these data the Baltic Shield lid can be divided into areas of different $P$ wave velocity (Fig. 14a): normal velocity (approximately corresponding to the area of Sweden), faster velocities (central and southern Finland), the fastest velocities (at southeastern edge of shield), and the lowest velocities (coincides with the northern part of the Baltic Shield and the Caledonides in northern Finland and northern Norway).

\section{SED}

$5,699-736,2013$

\section{Seismic LAB or LID? \\ The Baltic Shield case}

M. Grad et al.

\section{Title Page}

\section{Abstract}

Introduction

Conclusions

Tables

References

Figures

14

$\rightarrow$

4

Back

Close 


\section{Summary of the upper mantle strucure}

The seismic structure of the lithosphere-asthenosphere system beneath the Baltic Shield was studied using local earthquakes with magnitudes in the range 2.7-5.9. Good quality records up to $2200-3000 \mathrm{~km}$ distance were obtained by relatively densely

5 located seismic stations with spacing in the distance range $30-100 \mathrm{~km}$. All the data were corrected for topography and the Moho depth for each event and each station location, using reference model of the Baltic Shield with $46 \mathrm{~km}$ thick crust. A summary of the Baltic Shield structure is compiled in Fig. 14, showing a map of velocity provinces (Fig. 14a), $\mathrm{P}$ wave velocities in lid (Fig. 14b), and $\mathrm{P}$ and $\mathrm{S}$ wave velocities in the upper 10 mantle (Fig. 14c).

In general, $\mathrm{P}$ and $\mathrm{S}$ arrivals observed in the Baltic Shield are significantly earlier than predicted by the iasp91 global velocity model, which clearly indicates that lithospheric $P$ and $S$ velocities of the Baltic Shield are higher (see Figs. 6b, $c$ and $7 b, c)$.

For the two northern events (Spitsbergen and Novaya Zemlya) we observe a LVL that 15 we interpret as the asthenosphere. The LAB beneath Barents Sea was found at depth $198 \mathrm{~km}$ and $201 \mathrm{~km}$ for event no. 2 (Spitsbergen) and for event no. 8 (Novaya Zemlya), respectively. The location of deepest points reached by rays in the lithosphere are shown in the map (Fig. 14a) by two red circles, and red dotted line shows approximately $200 \mathrm{~km}$ isoline of the LAB depth. Other data show that LAB in the central Baltic Shield, if it exists, should be deeper than $200-250 \mathrm{~km}$. These depths coincide with results of surface wave tomography of the Barents Sea and surrounding regions (Levshin et al., 2007), as well as thermal modelling of the East European Craton (Artemieva 2003, 2007). The asthenosphere thickness for events at Spitsbergen and Novaya Zemlya were determined only from $P$ waves, and they are 69 and $61 \mathrm{~km}$, respectively (see gray lines in Fig. 14c). Analysis of the other record sections show that first arrivals of $P$ waves are continuous in the whole range of registration, while corresponding $S$ waves are weaker. This can be explained by lowering of $S$ wave velocity or decrease of the quality factor for $S$ waves ( $S$ wave asthenosphere?).

\section{SED}

$5,699-736,2013$

\section{Seismic LAB or LID? \\ The Baltic Shield case}

M. Grad et al.

\section{Title Page}


From analysis of record sections from different areas in the Baltic Shield, the lid of the shield can be divided into areas of different $P$ wave velocity. In Fig. 14a the area of normal velocity is marked in red (approximately corresponding to the area of Sweden), area of faster velocities is marked in blue (central and southern Finland), area of 5 the fastest velocities is marked in navy blue (at the southeastern edge of shield), and the area of the lowest velocities is marked in green (coincides with the northern part of the Baltic Shield and the Caledonides in northern Finland and northern Norway). The corresponding models of $P$ wave velocity are shown in the same colors in Fig. 14. Differentiation of the velocity could be interpreted as inhomogeneity of the lid. Howo ever, another interpretation could be anisotropy of the lithosphere, with fast velocity direction close to east-west, and slow velocity direction close to south-north. Recently, Eken et al. (2012) interpreted distinct differences in tomographic inversions of SV- and $\mathrm{SH}$ wave traveltimes as associated with anisotropy of the lithospheric mantle down to depths of about $200 \mathrm{~km}$. Amplitudes of the velocity perturbations decrease below $\sim 200 \mathrm{~km}$, that is sub-lithospheric mantle (asthenosphere?).

Apart of regional velocity differentiation we found small scale lithospheric inhomogeneities. Beneath southern Sweden, $15 \mathrm{~km}$ below the Moho, a LVL of $16 \mathrm{~km}$ thickness with a drop of velocity for $P$ waves $-0.33 \mathrm{~km} \mathrm{~s}^{-1}$ was found. Reflected waves and multiples in the LVL agree well with observations (Fig. 11). For the same area of southern Sweden at a similar depth a lithospheric reflector was found from FENNOLORA data (e.g. Guggisberg 1986), as well as in the uppermost mantle beneath southern Finland from local events registered by the SVEKALAPKO seismic array (Yliniemi et al., 2004).

\section{Conclusions}

- The asthenosphere was found in the area north of the Baltic Shield (beneath the

$$
\text { Barents Sea) at depth of about } 200 \mathrm{~km} \text {. }
$$

\section{SED}

$5,699-736,2013$

\section{Seismic LAB or LID? \\ The Baltic Shield case}

\section{Grad et al.}

\section{Title Page}

\section{Full Screen / Esc}

Printer-friendly Version

Interactive Discussion 
- No evidence was found for the asthenosphere beneath the Baltic Shield - it has to be deeper than $200 \mathrm{~km}$ if it exists at all. Even if it exists deeper it could not be detected by "refraction" method. For distance larger than about $2000 \mathrm{~km}$ a shadow zone in the first arrivals would be masked by deeper waves from the "410" and "660" km boundaries.

- Difficulties in the interpretation of next arrivals result from the complicated source function of natural earthquakes (e.g. event no. 2) or from multireflections in the LVL (event no. 1). Interpretation can also be complicated by seismic noise when signals from distant earthquakes are not strong enough, or obscured by simultaneous recording of small local events (see event no. 9 and event no. 10).

- Differentiation of the velocity in the lid could be interpreted as regional inhomogeneity or anisotropy, however it needs more studies using 3-D tomography.

- Answer for the question in the title: "LAB or LID?" - LID beneath the Baltic Shield!

Acknowledgements. The authors wish to thank Finnish Academy of Science and Letters, 15 Väisälä Foundation for financial support. This work was partially supported by NCN grants UMO-2011/01/B/ST10/06653 and DEC-2011/02/A/ST10/00284. We are also grateful to the staff at the Swedish National Seismic Network (SNSN) for giving us access to their data. Waveform data from seismic stations operated by the Institute of Seismology of the University of Helsinki, the Sodankylä Geophysical Observatory of the University of Oulu and from the National Swedish Seismic Network (SNSN) were used in this study. For specific events data from Norwegian and Russian stations were made available by the Bergen Seismological Observatory and NORSAR in Norway. The authors wish to thank GEOFON, GFZ German Research Centre for Geosciences for earthquake information and waveform data. Geographic data handling and plotting was done with GMT software by P. Wessel and W.H.F Smith (Wessel and 25 Smith 1991, 1998).

\section{SED}

$5,699-736,2013$

\section{Seismic LAB or LID? \\ The Baltic Shield case}

M. Grad et al.

\section{Title Page}

\section{Full Screen / Esc}

Printer-friendly Version

Interactive Discussion 


\section{References}

Ahjos, T. and Uski, M.: Earthquakes in northern Europe in 1375-1989, Tectonophysics, 207, 1-23, updated catalogue (1375-2008) available at: http://www.seismo.helsinki, 1992.

Amante, C. and Eakins, B. W.: ETOPO1 1 Arc-Minute Global Relief Model: Procedures, Data Sources and Analysis, NOAA Technical Memorandum NESDIS NGDC-24, 19 pp., 2009.

Anderson, D. L. and Toksöz, M. N.: Surface waves on a spherical Earth, 1. Upper mantle structure from Love waves, J. Geophys. Res., 68, 3483-3500, 1963.

Artemieva, I. M.: Lithospheric structure, composition, and thermal regime of the East European Craton: implications for the subsidence of the Russian platform, Earth Planet. Sci. Lett., 213, 431-446, doi:10.1016/S0012-821X(03)00327-3, 2003.

Artemieva, I. M.: Dynamic topography of the East European craton: shedding light upon lithospheric structure, composition and mantle dynamics, Global Planet. Change, 58, 411-434, doi:10.1016/j.gloplacha.2007.02.013, 2007.

Artemieva, I. M. and Mooney, W. D.: Thermal thickness and evolution of precambrian lithosphere: a global study, J. Geophys. Res., 106, 16387-16414, 2001.

Arvidsson, R.: Fennoscandian earthquakes: whole crust rupturing related to postglacial rebound, Science, 274, 744-746, 1996.

Arvidsson, R. and Kulhanek, O.: Seismodynamics of Sweden deduced from earthquake focal mechanisms, Geophys. J. Int., 16, 377-392, 1994.

Båth, M.: Propagation of Sn and Pn to teleseismic distances, Pure Appl. Geophys., 64, 19-30, 1966.

Bogdanova, S. V., Gorbatschev, R., and Garetsky, R. G.: The East European Craton, in: Encyclopedia of Geology, vol. 2, edited by: Selley, R. C., Cocks, L. R., and Plimer, I. R., Elsevier, Amsterdam, 34-49, 2005.

Bogdanova, S., Gorbatschev, R., Grad, M., Janik, T., Guterch, A., Kozlovskaya, E., Motuza, G., Skridlaite, G., Starostenko, V., Taran, L., and EUROBRIDGE and POLONAISE Working Groups: EUROBRIDGE: new insight into the geodynamic evolution of the East European Craton, in: European Lithosphere Dynamics, edited by: Gee, D. G., and Stephenson, R. A., Geological Society, London, Memoirs, 32, 599-625, 2006.

Bruneton, M., Pedersen, H. A., Farra, R., Arndt, N. T., Vacher, P., Achauer, U., Alinaghi, A., Ansorge, J., Bock, G., Friedrich, W., Grad, M., Guterch, A., Heikkinen, P., Hjelt, S. E., Hyvonen, T. L., Ikonen, J. P., Kissling, E., Komminaho, K., Korja, A., Kozlovskaya, E.,
SED

5, 699-736, 2013

\section{Seismic LAB or LID? \\ The Baltic Shield \\ case}

M. Grad et al.

\section{Title Page}


Nevsky, M. V., Paulssen, H., Pavlenkova, N. I., Plomerova, J., Raita, T., Riznichenko, O. Y., Roberts, R. G., Sandoval, S., Sanina, I. A., Sharov, N. V., Shomali, Z. H., Tiikkainen, J., Wielandt, E., Wylegalla, K., Yliniemi, J., and Yurov, Y. G.: Complex lithospheric structure under the central Baltic Shield from surface wave tomography, J. Geophys. Res., 109, B10303, 5 doi:1029/2003JB002947, 2004.

Calcagnile, G.: The lithosphere-asthenosphere system in Fennoscandia, Tectonophysics, 90, 19-35, doi:10.1016/0040-1951(82)90251-7, 1982.

Calcagnile, G. and Panza, G. F.: Properties of the lithosphere-asthenosphere system in Europe with a view toward Earth conductivity, Pure Appl. Geophys., 125, 241-254, 1987.

10 Červenỳ, V., and Pšenčík, I.: SEIS83 - numerical modeling of seismic wave fields in 2-D laterally varying layered structure by the ray method, in: Documentation of Earthquake Algorithm, edited by: Engdahl, E. R., World Data Center A for Solid Earth Geophys, Boulder, Rep. SE35, 36-40, 1984.

Cara, M., Nercessian, A., and Nolet, G.: New inferences from higher mode data in western

15 Europe and northern Eurasia, Geophys. J. Royal Astron. Soc., 61, 459-478, 1980.

Dost, B.: Upper mantle structure under western Europe from fundamental and higher mode surface waves using the NARS array, Geophys. J. Int., 100, 131-151, 1990.

Draber, D., Guterch, B., and Lewandowska-Marciniak, H.: Local earthquakes recorded by Polish seismological stations 1995-1997, Publs. Inst. Geophys. Pol. Acad. Sci., B-24, 3-13, 2002.

20 Eaton, D. W., Darbyshire, F., Evans, R. L., Grütter, H., Jones, A. G., and Yuan, X.: The elusive lithosphere-asthenosphere boundary (LAB) beneath cratons, Lithos, 109, 1-22, doi:10.1016/j.lithos.2008.05.009, 2009.

Eken, T., Plomerová, J., Vecsey, L., Babuška, V., Roberts, R., Shomali, H., and Bodvarsson, R.: Effects of seismic anisotropy on P velocity tomography of the Baltic Shield, Geophys. J. Int., 188, 600-612, doi:10.1111/j.1365-246X.2011.05280.x, 2012.

Grad, M.: Seismic model of the Earth's crust and upper mantle for the east European platform, Phys. Earth Planet. Inter., 51, 182-184, 1988.

Grad, M. and Luosto, U.: Seismic models of the crust of the Baltic shield along the SVEKA profile in Finland, Ann. Geophys., 5, 639-650, 1987,

30 http://www.ann-geophys.net/5/639/1987/.

Grad, M. and Luosto, U.: Seismic velocities and Q-factors in the uppermost crust beneath the SVEKA profile in Finland, Tectonophysics, 230, 1-18, 1994.

\section{SED}

$5,699-736,2013$

\section{Seismic LAB or LID? \\ The Baltic Shield \\ case}

M. Grad et al.

\section{Title Page}

\section{Full Screen / Esc}

Printer-friendly Version

Interactive Discussion 
Grad, M., Guterch, A., and Lund, C.-E.: Seismic models of the lower lithosphere beneath the southern Baltic Sea between Sweden and Poland, Tectonophysics, 189, 219-227, 1991.

Grad, M., Tiira, T., and ESC Working Group: The Moho depth map of the European Plate, Geophys. J. Int., 176, 279-292, doi:10.1111/j.1365-246X.2008.03919.x, 2009.

5 Gregersen, S., Voss, P., Shomali, Z. H., Grad, M., Roberts, R. G., and TOR Working Group: Physical differences in the deep lithosphere of Northern and Central Europe, in: European Lithosphere Dynamics, edited by: Gee, D. G., and Stephenson, R. A., Geological Society, London, Memoirs, 32, 313-322, 2006.

Guggisberg, B.: Eine zweidimensionale refraktionseismische Interpretation der Geschwindigkeits-Tiefen-Structur des oberen Erdmantels unter dem Fennoskandischen Shild (Projekt FENNOLORA), Diss. ETH Nr 7945, 199 pp., Zürich, 1986.

Gutenberg, B.: Physics of the Earth's Interior, Academic Press, New York, 240 pp., 1959.

Hirschleber, H. B., Lund, C.-E., Meissner, R., Vogel, A., and Weinrebe, W.: Seismic investigations along the Scandinavian blue road traverse, J. Geophys., 41, 135-148, 1975.

FENNIA Working Group: P and S Velocity Structure of the Fennoscandian Shield Beneath the FENNIA Profile in Southern Finland, Inst. Seismology, Univ. Helsinki Rep., S-38, 14 pp., 1998.

Hill, P.: An Earth-flattening transformation for waves from a pont source, Bull. Seism. Soc. Am., 62, 1195-1210, 1972.

20 Hyvönen, T., Tiira, T., Korja, A., Heikkinen, P., Rautioaho, E., and SVEKALAPKO Seismic Tomography Working Group: A tomographic crustal velocity model of the central Fennoscandian Shield, Geophys. J. Int., 168, 1210-1226, 2007.

Johnson, L. R.: Array measurements of $\mathrm{P}$ velocities in the upper mantle, J. Geophys. Res., 72 , 6309-6325, 1967.

Kennett, B. L. N. and Engdahl, E. R.: Traveltimes for global earthquake locations and phase identifications, Geophys. J. Int., 105, 429-465, 1991.

Korja, T.: How is the European Lithosphere imaged by magnetotellurics? Surv. Geophys., 28, 239-272, doi:10.1007/s10712-007-9024-9, 2007.

Kozlovskaya, E., Kosarev, G., Aleshin, I., Riznichenko, O., and Sanina, I.: Structure and composition of the crust and upper mantle of the Archean-Proterozoic boundary in the Fennoscandian shield obtained by joint inversion of receiver function and surface wave phase velocity of recording of the SVEKALAPKO array, Geophys. J. Int., 175, 135-152, doi:10.1111/j.1365246X.2008.03876.x, 2008.

\section{SED}

$5,699-736,2013$

\section{Seismic LAB or LID? \\ The Baltic Shield case}

M. Grad et al.

\section{Title Page}

\section{Full Screen / Esc}

Printer-friendly Version

Interactive Discussion 
Levshin, A. L., Schweitzer, J., Weidle, C., Shapiro, N. M., and Ritzwoller, M. H.: Surface wave tomography of the Barents Sea and surrounding regions, Geophys. J. Int., 170, 441-459, doi:10.1111/j.1365-246X.2006.03285.x, 2007.

$\mathrm{Li}, \mathrm{X}$., Yuan, X., and Kind, R.: The lithosphere-asthenosphere boundary beneath the west5 ern United States, Geophys. J. Int., 170, 700-710, doi:10.1111/j.1365-246X.2007.03428.X, 2007.

Lund, C.-E.: The fine structure of the lower lithosphere underneath the blue road profile in northern Scandinavia, Tectonophysics, 56, 111-122, 1979.

Luosto, U.: Reinterpretation of Sylen-Porvoo refraction data, Inst. Seismology, Univ. Helsinki Rep., S-13, 19 pp., 1986.

Luosto, U.: Structure of the Earth's crust in Fennoscandia as revealed from refraction and wideangle reflection studies, Geophysica, 33, 3-16, 1997.

Luosto, U., Flüh, E. R., Lund, C.-E., and Working Group: The crustal structure along the POLAR profile from seismic refraction investigations, Tectonophysics, 162, 51-85, 1989.

Luosto, U., Tiira, T. Korhonen, H., Azbel, I., Burmin, V., Buyanov, A., Kosminskaya, I., Ionkis, V., and Sharov, N.: Crust and upper mantle structure along the DSS Baltic profile in SE Finland, Geoph. J. Int., 101, 89-110, doi:10.1111/j.1365-246X.1990.tb00760.x, 1990.

Luosto, U., Grad, M., Guterch, A., Heikkinen, P., Janik, T., Komminaho, K., Lund, C., Thybo, H., and Yliniemi, J.: Crustal structure along the SVEKA'91 profile in Finland, in European Seismological Commission, XXIV General Assembly, 19-24 September 1994, Athens, Greece, in: Proceedings and Activity Report 1992-1994, vol. 2, edited by: Makropoulos, K., and Suhadolc, P., pp. 974-983, 1994.

Martinec, Z. and Wolf, D.: Inverting the Fennoscandian relaxation-time spectrum in terms of an axisym-metric viscosity distribution with a lithospheric root, J. Geod., 39, 143-163, 2005.

Meissner, R.: The Continental Crust - a Geophysical Approach, International Geophysics Series, Academic Press Inc., Orlando, 34, 426 pp., 1986.

Nolet, G.: The upper mantle under Western Europe inferred from the dispersion of Rayleigh modes, J. Geophys., 43, 265-285, 1977.

Olsson, S.: Analyses of Seismic Wave Conversion in the Crust and Upper Mantle beneath the Baltic Shield, Ph.D. thesis, Digital Comprehensive Summaries of Uppsala Dissertations from the Faculty of Science and Technology, 319. 2007.

\section{SED}

5, 699-736, 2013

\section{Seismic LAB or LID? \\ The Baltic Shield case}

M. Grad et al.

\section{Title Page}

\section{Full Screen / Esc}

Printer-friendly Version

Interactive Discussion 
Panza, G. F.: Lateral variations in the lithosphere in correspondence of the Southern Segment of EGT, in: Second EGT Workshop: the Southern Segment, edited by: Galson, D. A. and Mueller, St., 47-51, ESF, Strasbourg, France, 1985.

Pasyanos, M. E.: Lithospheric thickness modeled from long-period surface wave dispersion, Tectonophysics, 481, 38-50, 2010.

Pirli, M., Schweitzer, J., Ottemöller, L., Raeesi, M., Mjelde, R., Atakan, K., Guterch, A., Gibbons, S. J., Paulsen, B., Dębski, W., Wiejacz, P., and Kværna, T.: Preliminary analysis of the 21 February 2008 Svalbard (Norway) seismic sequence, Seismol. Res. Lett., 81, 63-75, 2010.

10 Plomerová, J. and Babuška, V.: Long memory of mantle lithosphere fabric - European LAB constrained from seismic anisotropy, Lithos, 120, 131-143, doi:10.1016/j.lithos.2010.01.008, 2010.

Schubert, G., Froidevaux, C., and Yuen, D. A.: Oceanic lithosphere and asthenosphere: thermal and mechanical structure, J. Geophys. Res., 81, 3525-3540, 1976.

15 Slunga, R.: The Baltic Shield earthquakes, Tectonophysics, 189, 323-331, 1991.

Stacey, F. D.: Physics of the Earth, John Wiley and Sons, New York, 1969.

Tiira, T., Janik, T., Kozlovskaya, E., Grad, M., Korja, A., Komminaho, K., Hegedüs, E., Kovács, C. A., Silvennoinen, H., and Brückl, E.: Crustal architecture of the inverted Central Lapland rift along HUKKA 2007 profile, Tectonophysics, submitted, 2013.

20

Uski, M. and Raime, M.: Earthquakes in Northern Europe in 2008, Univ. Inst. Seismology, Univ. Helsinki, Rep., R-271, 1-36, 2010.

Uski, M., Tiira, T., Grad, M., and Yliniemi, J.: Crustal seismic structure and depth distribution of earthquakes in the Archean Kuusamo region, Fennoscandian Shield, J. Geod., 53, 61-80, doi:10.1016/j.jog.2011.08.005, 2012.

Wessel, P. and Smith, W. H. F.: Free software helps map and display data, EOS Trans. AGU, 72, 445-446, 1991.

Wessel, P. and Smith, W. H. F.: New, improved version of Generic Mapping Tools released, EOS Trans. AGU, 79, 579, 1998.

Wiejacz, P. and Rudziński, Ł.: Seismic event of 22 January 2010 near Bełchatów, Poland, Acta Geophys., 58, 988-994, doi:10.2478/s11600-010-0030-9, 2010.

Wilde-Piórko, M., Świeczak, M., Grad, M., and Majdański, M.: Integrated seismic model of the crust and upper mantle of the Trans-European Suture zone between the Precam-
SED

5, 699-736, 2013

\section{Seismic LAB or LID? \\ The Baltic Shield \\ case}

M. Grad et al.

Title Page

Abstract

Introduction

Conclusions

References

Tables

Figures

14

$\rightarrow$

4

Back

Close

\section{Full Screen / Esc}

Printer-friendly Version

Interactive Discussion 
brian craton and Phanerozoic terranes in Central Europe, Tectonophysics, 481, 108-115, doi:10.1016/j.tecto.2009.05.002, 2010.

Yliniemi, J., Kozlovskaya, E., Hjelt, S.-E., Komminaho, K., and Ushakov, A.: Structure of the crust and uppermost mantle beneath southern Finland revealed by analysis of local events registered by the SVEKALAPKO seismic array, Tectonophysics, 394, 41-67, 2004.

Zelt, C. A.: ZPLOT - an iteractive plotting and picking program for seismic data, Bullard Lab., Univ. of Cambridge, Cambridge UK, 1994.

Zielhuis, A. and Nolet, G.: The deep seismic expression of an ancient plate boundary in Europe, Science, 265, 79-81, 1994. case

M. Grad et al.

\section{Title Page}

\section{Full Screen / Esc}




\section{Seismic LAB or LID? The Baltic Shield case}

Table 1. Events used for lithospheric structure studies in the Baltic Shield area data compiled from Helsinki catolog Uski and Raime (2010), Pirli et al. (2010) and Wiejacz and Rudziński (2010).

\begin{tabular}{llllllll}
\hline event no. & date yyyy-mm-dd & time hh:mm:ss & lat $\phi\left[{ }^{\circ} \mathrm{N}\right]$ & long $\lambda\left[{ }^{\circ} \mathrm{E}\right]$ & depth $[\mathrm{km}]$ & $M$ & place \\
\hline 1 & $2008-01-24$ & $18: 51: 51.4$ & 57.63 & 7.37 & 10.0 & 2.7 & Skagerak \\
2 & $2008-02-21$ & $02: 46: 17.6$ & 77.01 & 19.01 & 15.4 & 5.9 & Spitsbergen \\
3 & $2008-06-13$ & $04: 13: 30.4$ & 51.54 & 16.07 & 4.1 & 4.3 & Lubin \\
4 & $2008-10-14$ & $16: 47: 42.2$ & 69.74 & 30.14 & 2.7 & 3.0 & Varangerfjord \\
5 & $2008-12-12$ & $05: 20: 03.1$ & 55.57 & 13.53 & 19.6 & 4.9 & Scania \\
6 & $2009-05-25$ & $08: 05: 50.8$ & 67.65 & 33.99 & 1.0 & 3.4 & Kola \\
7 & $2010-01-22$ & $04: 05: 42.1$ & 51.18 & 19.09 & 4.1 & 4.3 & Betchatów \\
8 & $2010-10-11$ & $22: 48: 28.0$ & 76.28 & 63.95 & 10.0 & 4.7 & Novaya Zemlya \\
9 & $2011-02-14$ & $12: 43: 11.0$ & 50.37 & 07.79 & 12.0 & 4.0 & Rhine Graben \\
$(10)$ & $2011-02-14$ & $12: 47: 28.7$ & 64.12 & 24.27 & 0.0 & 1.1 & Western Finland \\
\hline
\end{tabular}

Title Page

Abstract

Introduction

Conclusions

References

Tables

Figures

14

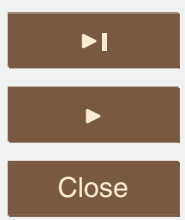

Back

Close

Full Screen / Esc

Printer-friendly Version

Interactive Discussion 


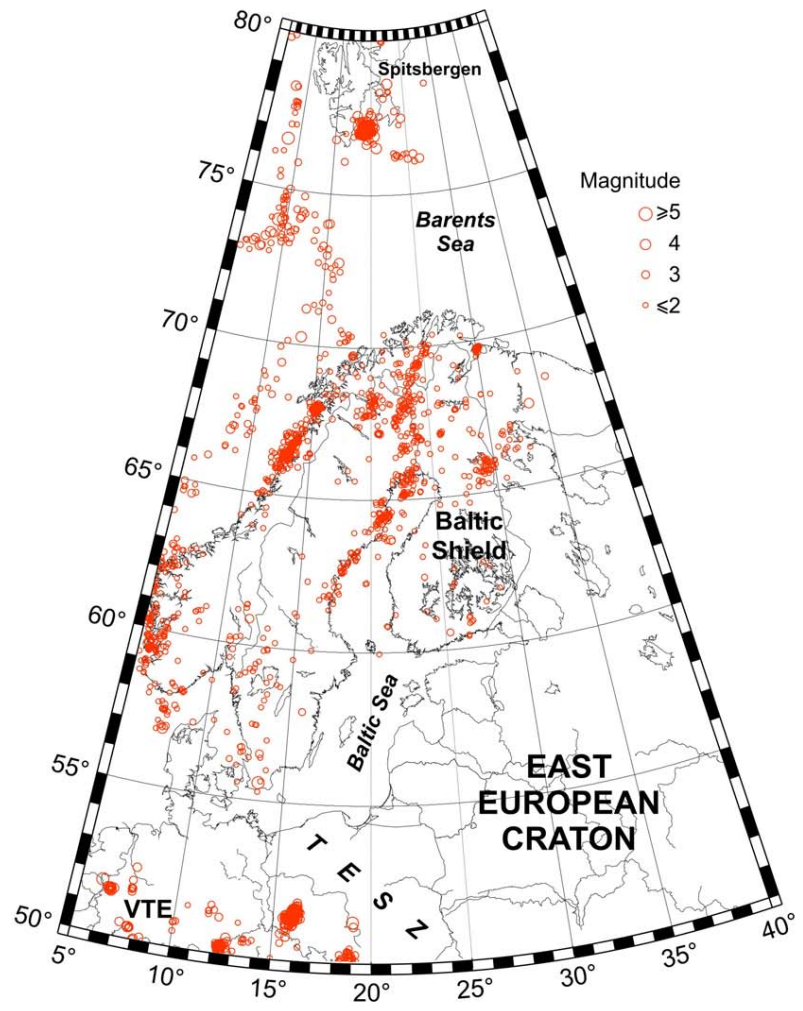

Fig. 1. The seismicity map of the Central and Northern Europe (January 2008-September 2011) showing location of 2698 events: 2285 from Helsinki catalog (Uski and Raime, 2010) and 413 from GEOFON. Events are mostly shallow: $90 \%$ of events have depth less than $20 \mathrm{~km}$, maximum depth is $70 \mathrm{~km}$ for event in Spitsbergen; the highest magnitude for an event is 5.9.

\section{SED}

$5,699-736,2013$

Seismic LAB or LID? The Baltic Shield case

M. Grad et al.

\section{Title Page}

4

Back

$>$

\section{Close}

\section{Full Screen / Esc}

Printer-friendly Version

Interactive Discussion 


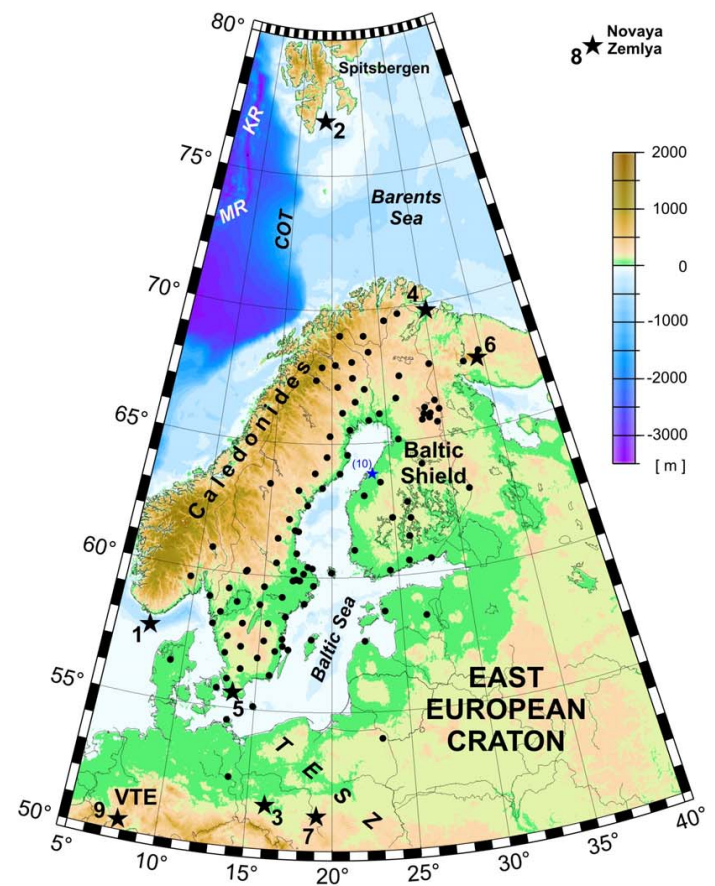

Fig. 2. The location of nine events (numbered black stars) and seismic stations (dots) used in this paper for the study of the lithosphere-asthenosphere system beneath the Baltic Shield, overlain on the topography/bathymetry map of the region (Amante and Eakins, 2009). The blue star with number 10 shows the location of a small event which occured in Western Finlad and was recorded together with event no. 9. For more details see Table 1. TESZ - Trans European suture zone, SW margin of the East European platform; VTE - Variscan terranes of Europe; KR and MR - Knipovich and Mohns ridges, parts of Mid-Atlantic Ridge; COT - continent-ocean transition.
SED

$5,699-736,2013$

Seismic LAB or LID? The Baltic Shield case

M. Grad et al.

\section{Title Page}

4

Back

$>$

Close

\section{Full Screen / Esc}

Printer-friendly Version

Interactive Discussion 


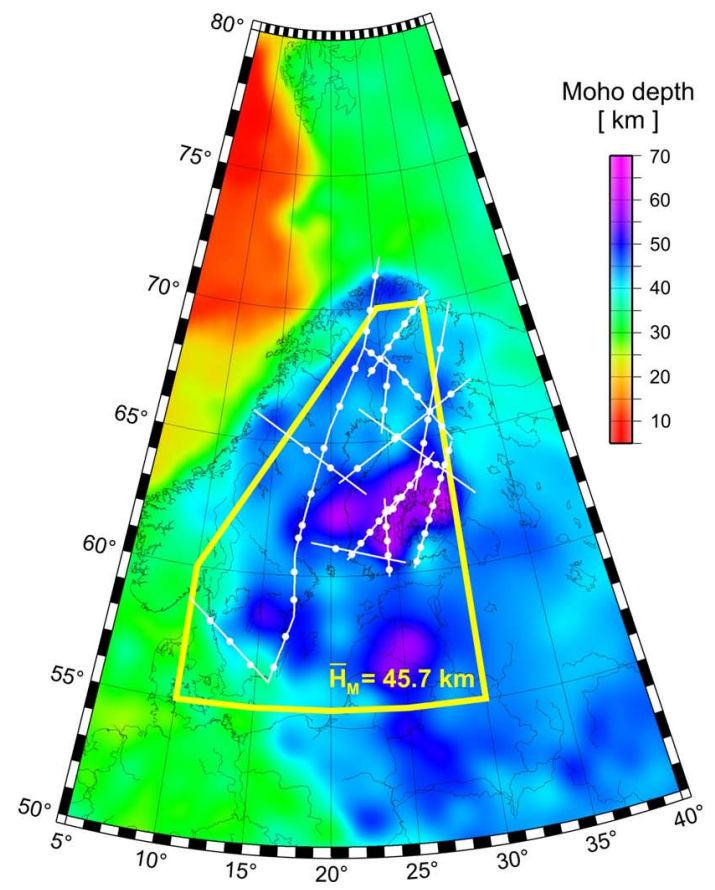

Fig. 3. Moho depth map of the European Plate (Grad et al., 2009). Also shown are the seismic refraction profiles (white lines) with the positions (white dots) where velocities were sampled to compile the average $P$ wave velocity model of the crust and uppermost mantle of the Baltic Shield. The yellow frame shows the area for which an average Moho depth $(45.7 \mathrm{~km})$ was calculated. Data were compiled from Hirschleber et al. (1975); Lund (1979); Guggisberg (1986); Luosto (1986); Grad and Luosto (1987); Luosto et al. (1989, 1990, 1994); Grad et al. (1991); FENNIA Working Group (1998); Uski et al. (2012); Tiira et al. (2013).

\section{SED}

$5,699-736,2013$

\section{Seismic LAB or LID? The Baltic Shield case}

\section{Grad et al.}

\section{Title Page}

\section{Full Screen / Esc}

Printer-friendly Version

Interactive Discussion 

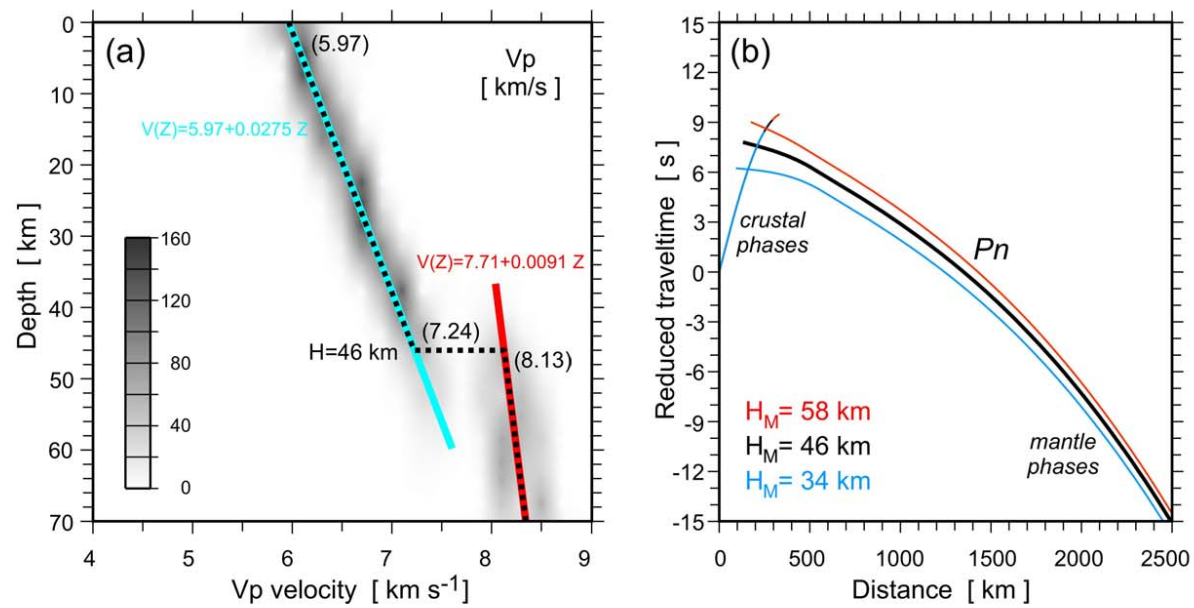

\section{Seismic LAB or LID? The Baltic Shield case}

\section{Grad et al.}

\section{Title Page}

Fig. 4. (a) Average $P$ wave velocities of the crust and uppermost mantle of the Baltic Shield fitted by the linear functions (1) and (2) given in the text. In total 4269 values of velocity in 67 locations were used (see white dots in Fig. 3). The gray scale shows the density of data in $0.1 \mathrm{~km}^{-1} 1 \times 1 \mathrm{~km}$ cells. The reference model shown by the black dotted line has $46 \mathrm{~km}$ thick crust with velocities increasing from 5.97 at the Earth's surface to $7.24 \mathrm{~km} \mathrm{~s}^{-1}$ at the $46 \mathrm{~km}$ depth. The velocity below the Moho at $46 \mathrm{~km}$ depth is $8.13 \mathrm{~km} \mathrm{~s}^{-1}$. (b) A comparison of traveltime curves for the reference model (black line for Moho depth $46 \mathrm{~km}$ ) with traveltime curves for shallower Moho (34 km depth, blue line) and deeper Moho (58 km depth, red line). Reduction velocity is $8 \mathrm{~km} \mathrm{~s}^{-1}$. For more explanation see text.

14

4

Back

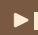

$>$

\section{Close}

\section{Full Screen / Esc}

Printer-friendly Version

Interactive Discussion 


\section{SED}

$5,699-736,2013$
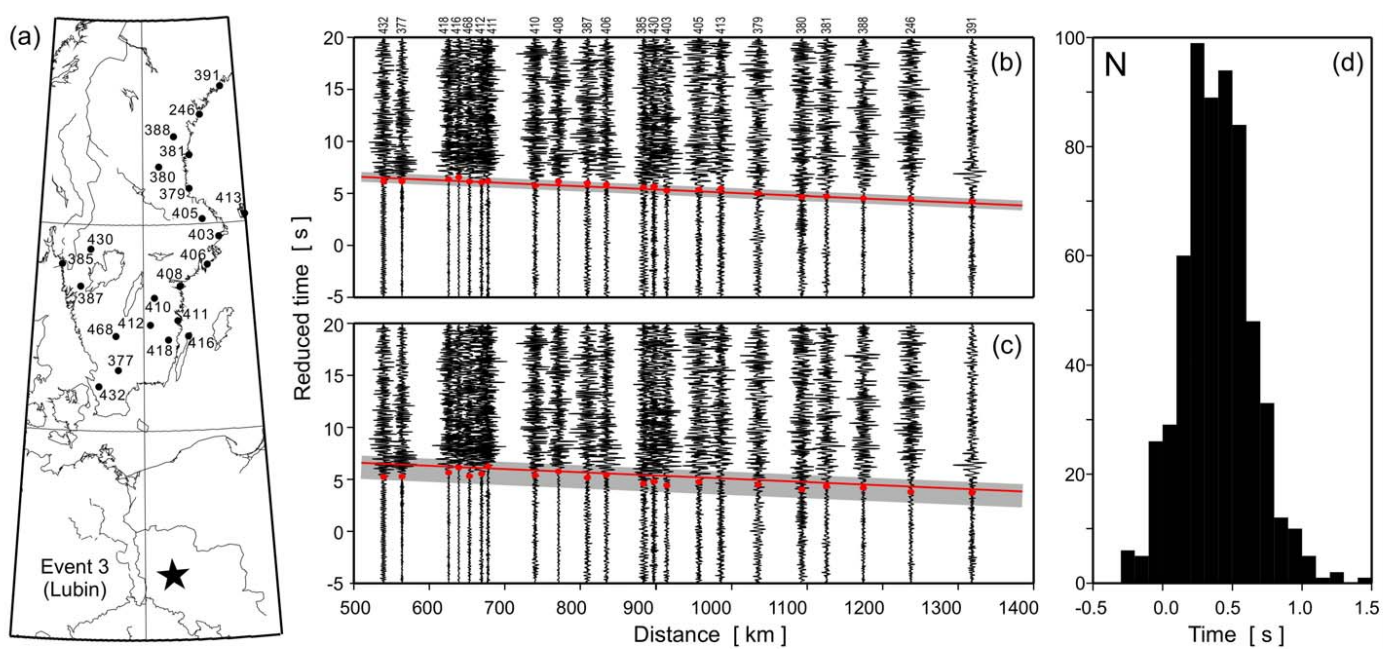

Fig. 5. Example of application of the time correction discussed in the text. (a) Map showing the location of event no. 9 (Rhine Graben) marked by star and seismic stations in southern Sweden (numbered dots) used in this comparison. (b) Recorded seismograms with time corrections applied. Note much lower scattering of first arrival times in the corrected section c. (c) Recorded seismograms without time corrections. Red dots are picked first arrivals for $\mathrm{P}$ waves, and thick gray line shows a scattering range of first arrival times; reduction velocity $8 \mathrm{~km} \mathrm{~s}^{-1}$. (d) Histogram showing distribution of 604 total time corrections. About $93 \%$ of corrections are in range from -0.1 to $0.8 \mathrm{~s}$, with maximum for $0.2-0.5 \mathrm{~s}$ interval (282 corrections).
Seismic LAB or LID? The Baltic Shield case

M. Grad et al.

\section{Title Page}

Abstract

Introduction

Conclusions

References

Tables

Figures

14

$\rightarrow 1$

4

Back

Close

\section{Full Screen / Esc}

Printer-friendly Version

Interactive Discussion 
Event 3 (Lubin)

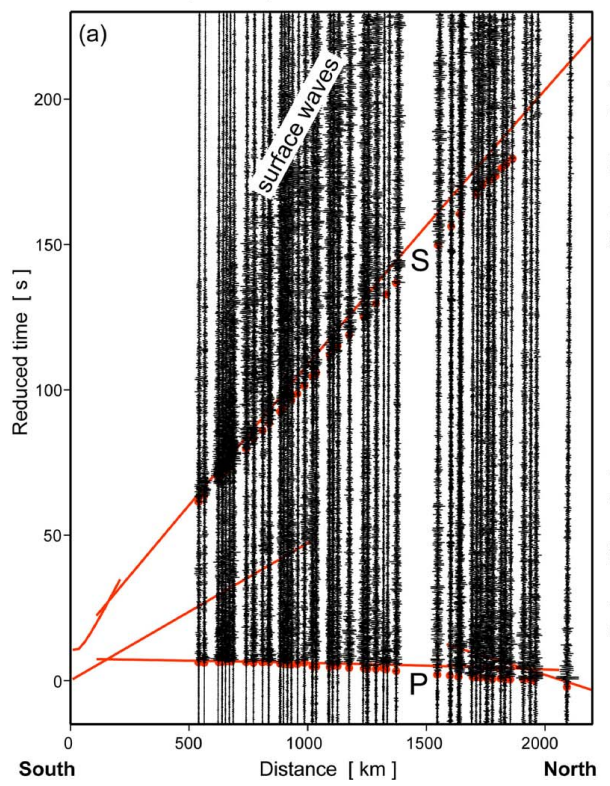

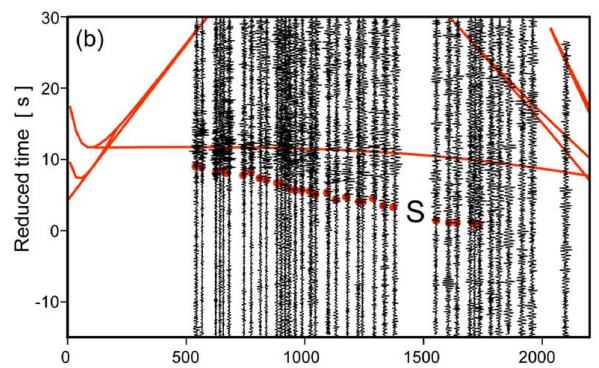

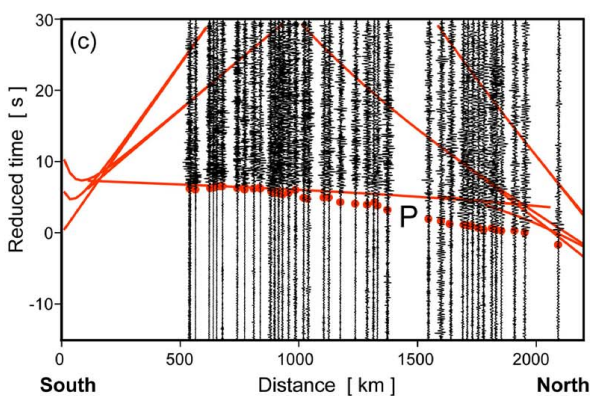

SED

5, 699-736, 2013

Seismic LAB or LID? The Baltic Shield case

\section{Grad et al.}

\section{Title Page}

Abstract

Introduction

Conclusions

References

Tables

Figures

14

4

Close (a) Full wave field of $P, S$ and surface waves. Filtration $1-7 \mathrm{~Hz}$, normalized traces, reduction velocity $8 \mathrm{~km} \mathrm{~s}^{-1}$. Red lines are first arrivals of $\mathrm{P}$ and $\mathrm{S}$ waves calculated for the iasp91 model. Enlarged parts of this section are shown for $P$ and $S$ waves. (b) Section for $S$ waves, filtration 2-7 Hz, normalized traces, reduction velocity $4.5 \mathrm{~km} \mathrm{~s}^{-1}$. (c) Section for $P$ waves, filtration 2$10 \mathrm{~Hz}$, normalized traces, reduction velocity $8 \mathrm{~km} \mathrm{~s}^{-1}$. Red dots are the picked first arrivals for $\mathrm{P}$ and $\mathrm{S}$ waves, and red lines are the first arrivals of $\mathrm{P}$ and $\mathrm{S}$ waves calculated for the iasp91 model. Phases related to the "410" and "660" km boundaries are also shown in the sections. Note the early arrivals of both $\mathrm{P}$ and $\mathrm{S}$ waves compared to the iasp91 model - at distance $1700 \mathrm{~km}$ about $4 \mathrm{~s}$ for $\mathrm{P}$ waves and about $8 \mathrm{~s}$ for $\mathrm{S}$ waves.

\section{Full Screen / Esc}

Printer-friendly Version

Interactive Discussion 


\section{Event 6 (Kola)}

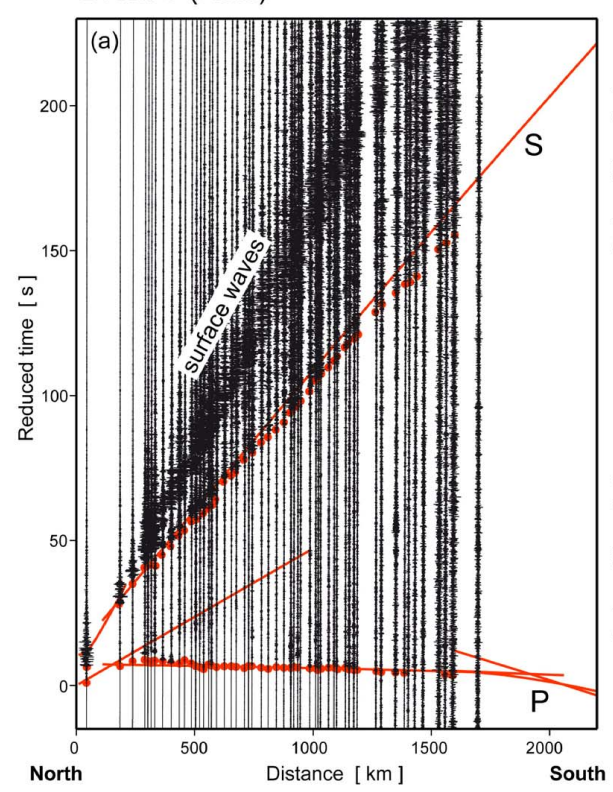

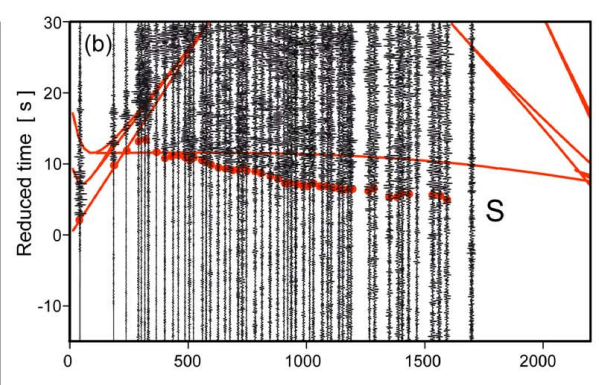

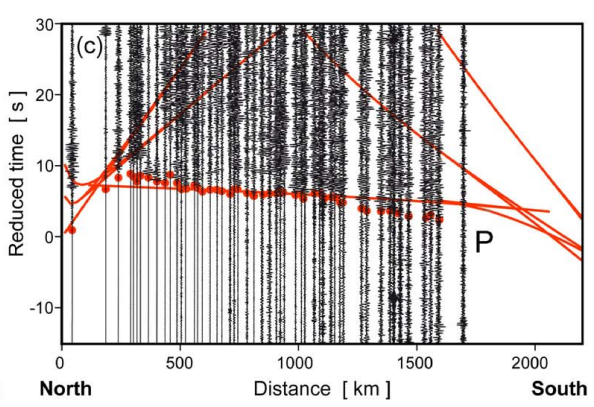

SED

$5,699-736,2013$

Seismic LAB or LID? The Baltic Shield case

M. Grad et al.

Fig. 7. Examples of record sections with time corrected seismograms for event no. 6 (Kola). (a) Full wave field of $P, S$ and surface waves. Filtration $1-7 \mathrm{~Hz}$, normalized traces, reduction velocity $8 \mathrm{~km} \mathrm{~s}^{-1}$. Red lines are the first arrivals of $P$ and $S$ waves calculated for the iasp91 model. Enlarged parts of this section are shown for $P$ and $S$ waves. (b) Section for $S$ waves, filtration 2-7 Hz, normalized traces, reduction velocity $4.5 \mathrm{~km} \mathrm{~s}^{-1}$. (c) Section for $P$ waves, filtration 2$10 \mathrm{~Hz}$, normalized traces, reduction velocity $8 \mathrm{~km} \mathrm{~s}^{-1}$. Red dots are the picked first arrivals for $\mathrm{P}$ and $\mathrm{S}$ waves, and red lines are the first arrivals of $\mathrm{P}$ and $\mathrm{S}$ waves calculated for the iasp91 model. Phases from " 410 " and "660" km boundaries are also shown. Note the early arrivals of both $\mathrm{P}$ and $\mathrm{S}$ waves compared to iasp91 model - at distance $1700 \mathrm{~km}$ about $3 \mathrm{~s}$ for $\mathrm{P}$ waves and about $6 \mathrm{~s}$ for $S$ waves. 


\section{SED}

$5,699-736,2013$

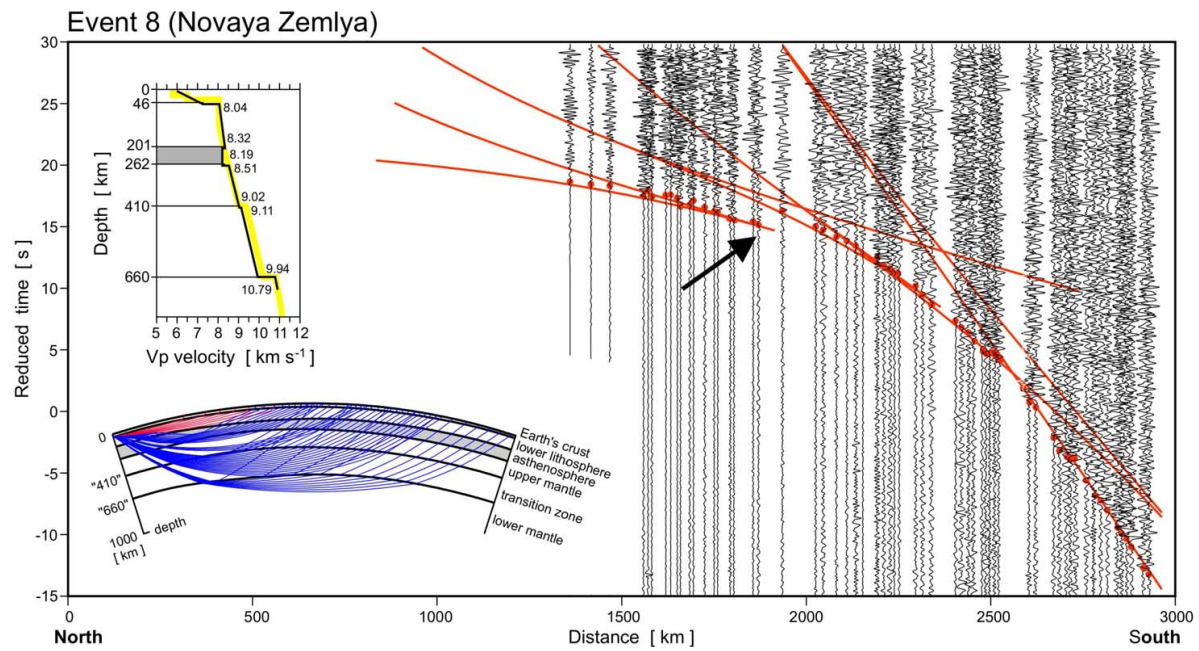

Fig. 8. Record section for event no. 8 (Novaya Zemlya). Filtration $1-5 \mathrm{~Hz}$, normalized traces, reduction velocity $8 \mathrm{~km} \mathrm{~s}^{-1}$. The beginning of the shadow zone of the first arrivals is observed at a distance of around $1900 \mathrm{~km}$ (shown by arrow), and the corresponding depth of the low velocity zone ( $L A B)$ is $201 \mathrm{~km}$. Red dots are picked the first arrivals of $P$ waves, and red lines are traveltimes. The $\mathrm{Vp}$ model (black line) is shown together with the iasp91 model (yellow line). The bottom left plot shows rays in the mantle (red in the lithosphere and navy blue in deeper mantle).

\section{Seismic LAB or LID? The Baltic Shield case}

\section{Grad et al.}

\section{Title Page}

4

\section{Back}

\section{Full Screen / Esc}

Printer-friendly Version

Interactive Discussion 

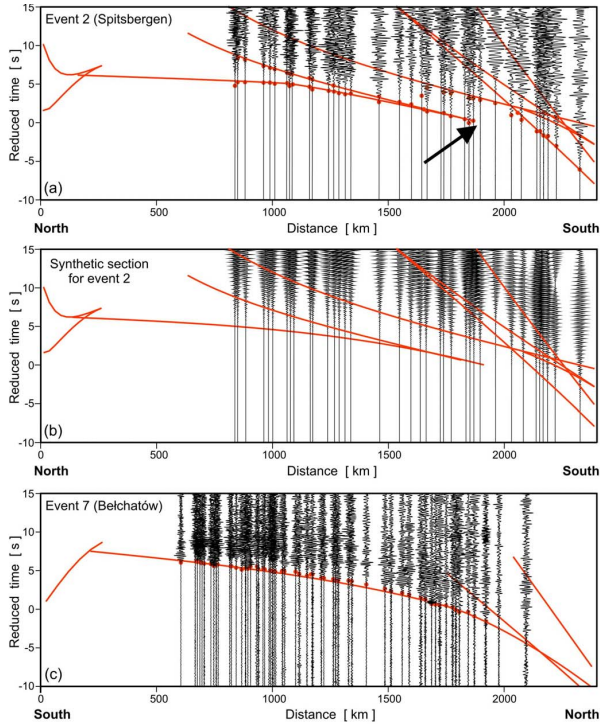

Fig. 9. Record sections of two events (with and without asthenosphere), together with traveltimes of the best fitted models. (a) Section of event no. 2 (Spitsbegen). Filtration $2-15 \mathrm{~Hz}$, normalized traces, reduction velocity $8 \mathrm{~km} \mathrm{~s}^{-1}$. The beginning of the shadow zone of the first arrivals (shown by arrow) is observed at distance of about $1800 \mathrm{~km}$, and corresponds to the depth of the low velocity zone (LAB) at $198 \mathrm{~km}$. (b) Synthetic seismograms for event no. 2 (Spitsbegen). For synthetics a complex source was simulated with a length of radiation of around $20 \mathrm{~s}$. The figure shows the difficulties in interpretation of secondary arrivals masked by long source function. However, the shadow zone in first arrivals is still clear, which permits conclusions about the LVL - asthenosphere. (c) Section for event no. 7 (Bełchatów). Filtration 2-15 Hz, normalized traces, reduction velocity $8 \mathrm{~km} \mathrm{~s}^{-1}$. A continuity of the first arrivals is observed in the whole distance range up to about $2000 \mathrm{~km}$. In this case the low velocity zone (asthenosphere) has to be deeper than $180-200 \mathrm{~km}$, if it exists at all. In all sections red dots are picked first arrivals of $P$ waves, and red lines are fitted traveltimes.
SED

5, 699-736, 2013

Seismic LAB or LID?

The Baltic Shield

case

M. Grad et al.

\section{Title Page}

Abstract

Introduction

Conclusions

References

Tables

Figures

14

Back

Close

\section{Full Screen / Esc}

Printer-friendly Version

Interactive Discussion 
Event 9 (Rhein Graben)

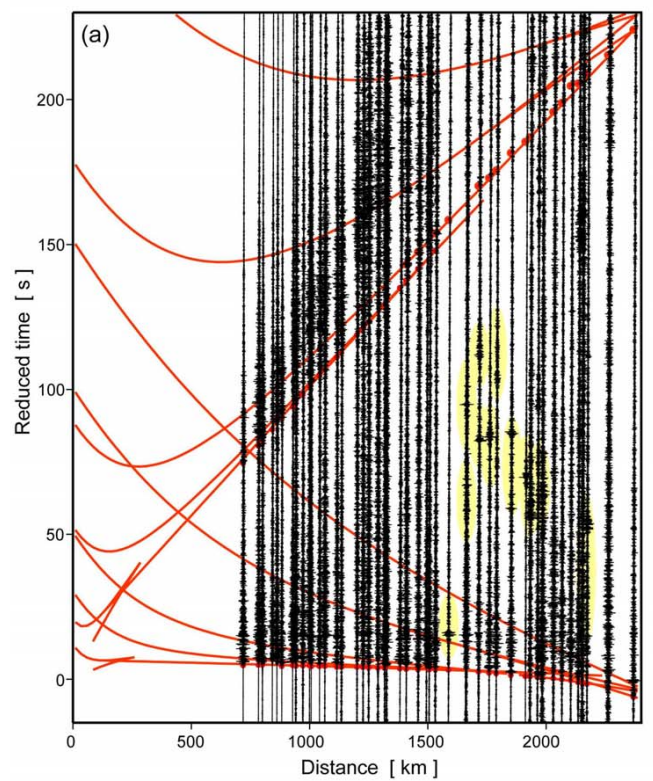

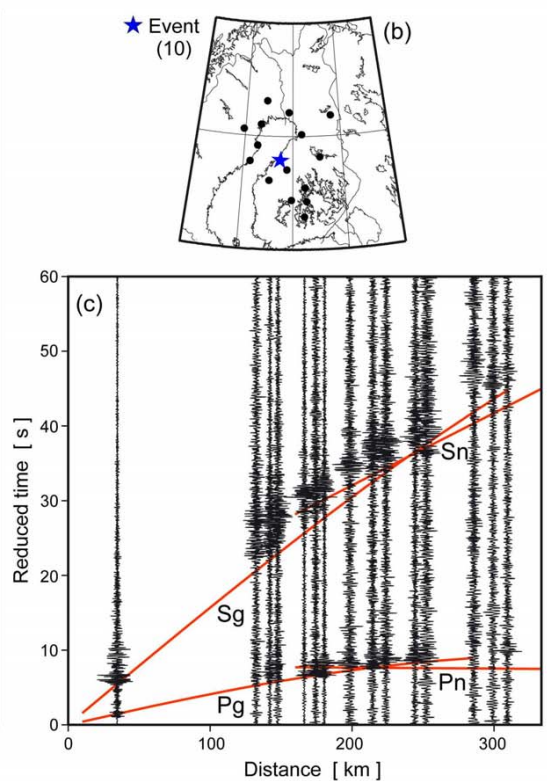

Fig. 10. Record section (a) for event no. 9 (Rhine Graben) with signals from simultaneous small event in Finland (no.10; highlighted by yellow). (b) Location of event 10 and seismic stations recording this event. (c) Record section of event 10 . Note the good fit of $\mathrm{P}$ and $\mathrm{S}$ traveltimes calculated for the reference model.

\section{Seismic LAB or LID? The Baltic Shield case}

\section{Grad et al.}

\section{Title Page}

Abstract

Introduction

Conclusions

References

Tables

Figures

14

$>$ I

Back

Close

\section{Full Screen / Esc}

Printer-friendly Version

Interactive Discussion

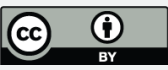


Event 1 (Skagerak)
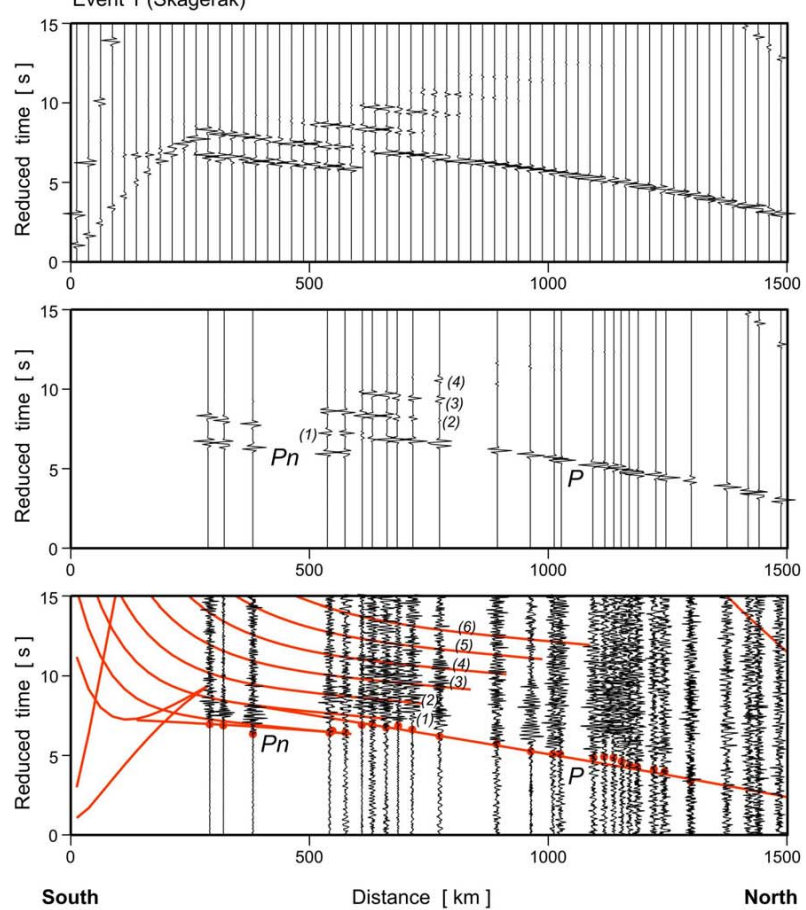

Fig. 11. Record section (bottom) for event no. 1 (Skagerak) with synthetic seismograms (middle and top). Note in the section a shadow zone (at distance of around $600 \mathrm{~km}$ ) which is an effect of a LVL in the lower lithosphere (at depth interval 61-77 km). Red lines show the first arrivals $(P n$ and $P)$, reflections from the bottom of the LVL (1) and traveltimes of five multiples in the LVL (2)-(6). Multiples in the LVL (2)-(4) explain the strong amplitudes in further arrivals in the distance range $600-800 \mathrm{~km}$.
SED

5, 699-736, 2013

Seismic LAB or LID? The Baltic Shield case

M. Grad et al.

\section{Title Page}

Abstract

Introduction

Conclusions

References

Tables

Figures

14

Back

Close

\section{Full Screen / Esc}

Printer-friendly Version

Interactive Discussion 


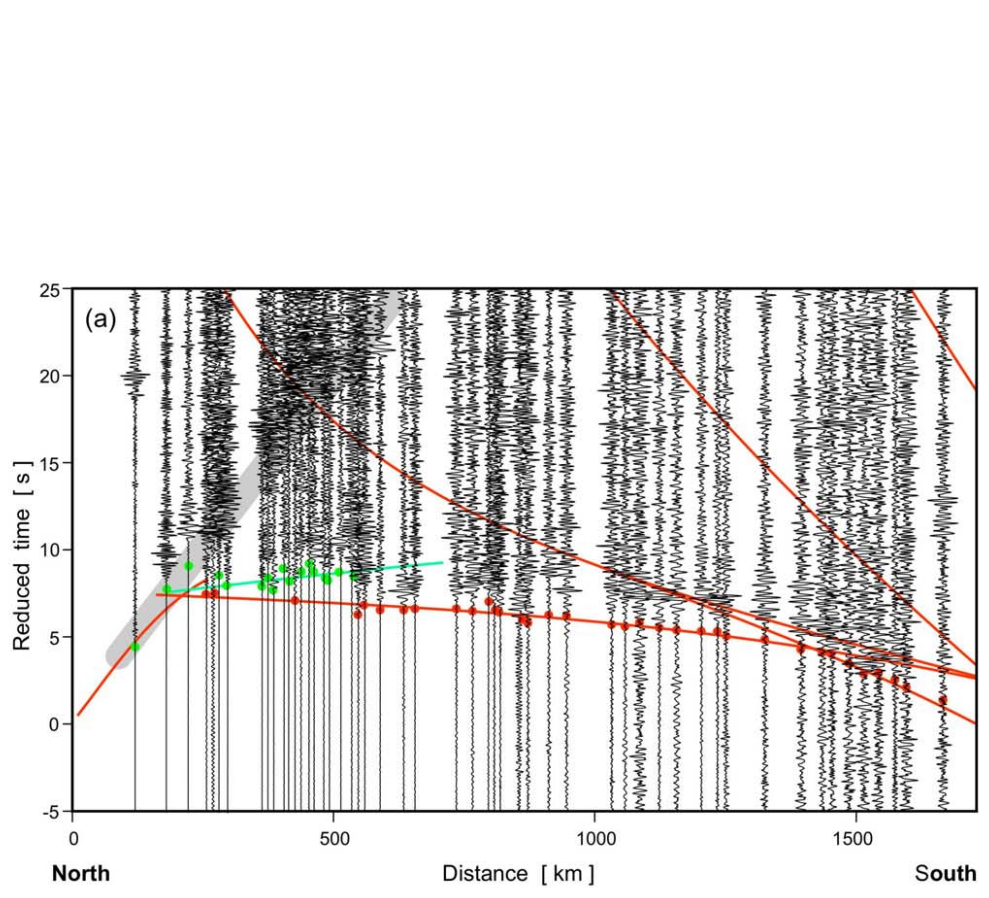

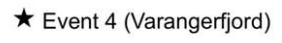

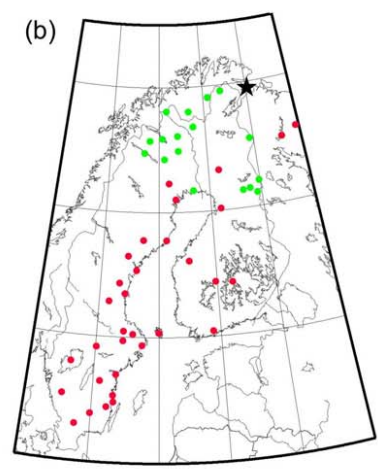

South

\section{SED}

5, 699-736, 2013

Seismic LAB or LID? The Baltic Shield case

M. Grad et al.

\section{Title Page}

Abstract

Introduction

Conclusions

References

Tables

Figures

14

$>1$

4

Back

$>$

fjord). Low velocities in the northern part of the Baltic Shield and the Caledonides (green dots), and normal to the south (red dots). Thick gray bar highlights far distance Pg waves recorded up to about $600 \mathrm{~km}$ distance. (b) Location map showing recording stations in corresponding colours.

Full Screen / Esc

Printer-friendly Version

Interactive Discussion 


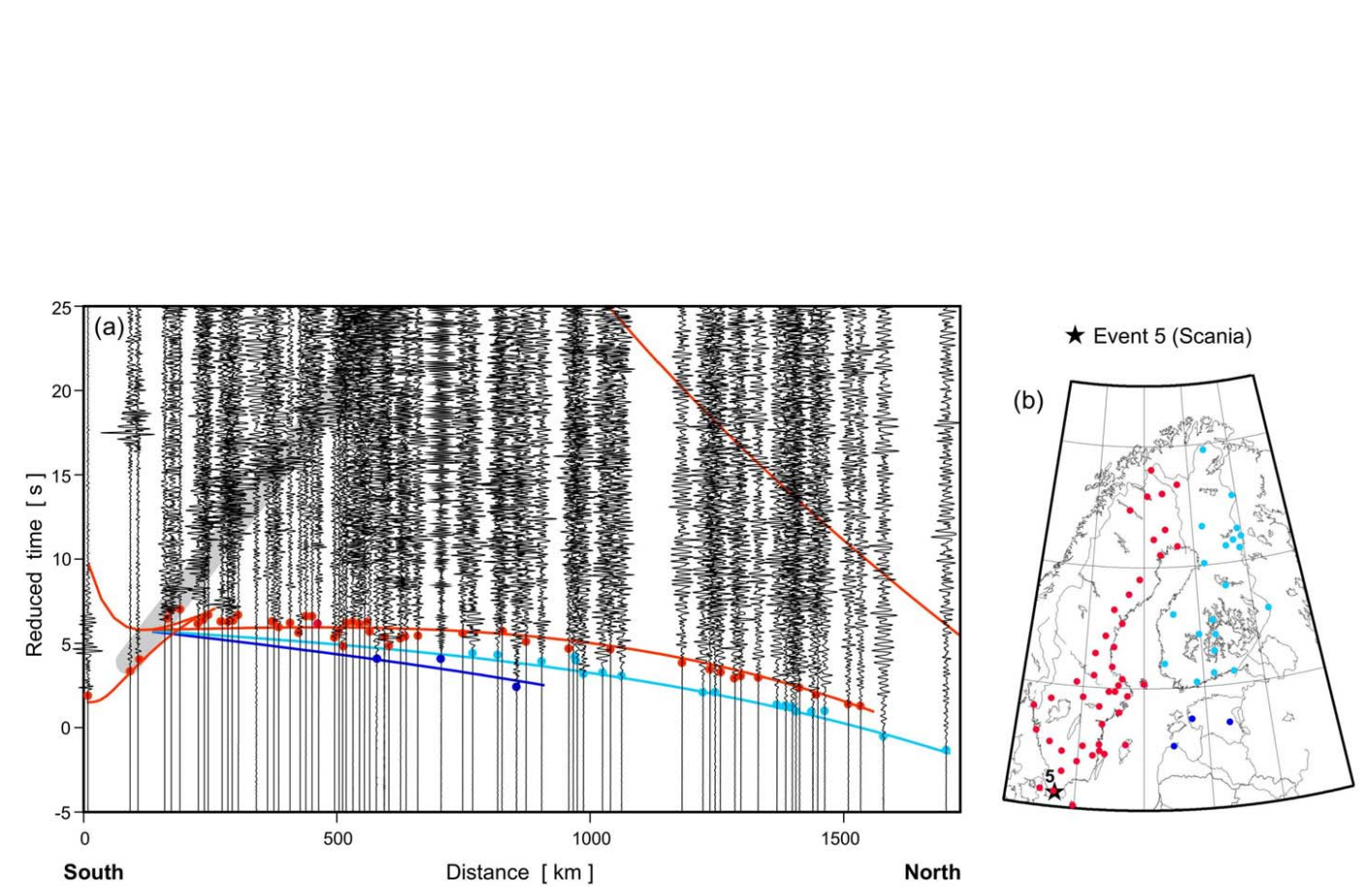

\section{SED}

$5,699-736,2013$

Seismic LAB or LID? The Baltic Shield case

M. Grad et al.

Title Page

Abstract

Introduction

Conclusions

References

Tables

Figures

$1<$

$>1$

Fig. 13. (a) Differentiation of the upper mantle velocities observed for event no. 5 (Scania). Normal velocities to the north (red dots), higher to NE (light blue dots), highest to the east (navy blue dots). Thick gray bar highlights far distance $\mathrm{Pg}$ waves recorded up to about $600 \mathrm{~km}$ distance. (b) Location map showing recording stations in corresponding colours.

4

Back

$>$

Full Screen / Esc

Printer-friendly Version

Interactive Discussion 

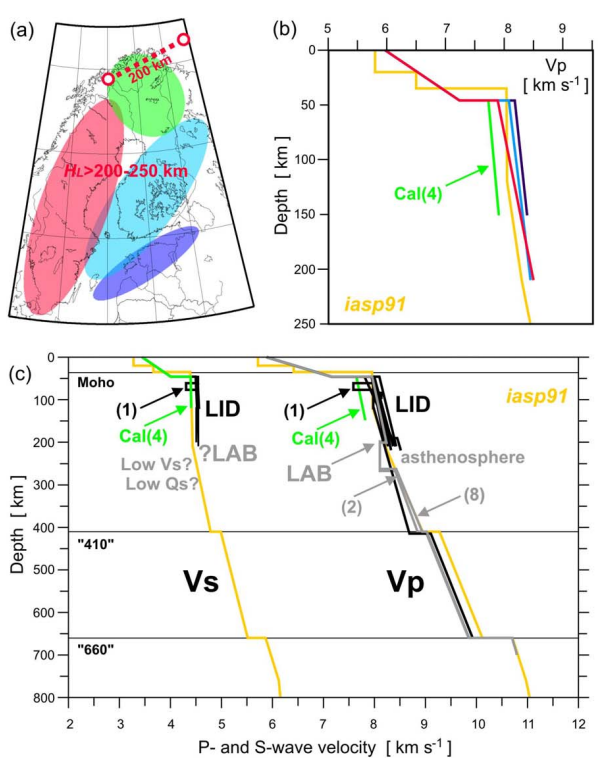

Fig. 14. Summary of the Baltic Shield structure. (a) Map showing regions of lithospheric mantle velocities: low in the Caledonides and the northern Baltic Shield (green), normal (red), higher (light blue) and highest in the east (navy blue dots). Two red circles in the north of the shield show locations of deepest rays from event no. 2 (Spitsbergen) and event no. 8 (Novaya Zemlya) corresponding to a LAB at $200 \mathrm{~km}$ depth in the Barents Sea. LAB in the central Baltic Shield should be deeper than 200-250 km. (b) Models of lithospheric mantle velocities for $P$ waves for events no. 4 (Varangerfjord, green line) and event no. 5 (Scania, all other lines). Colors correspond to those on adjacent map; iasp91 model (yellow line) is shown for comparison. (c) $\mathrm{P}$ and $\mathrm{S}$ wave velocity models for the Baltic Shield together with the iasp91 model (yellow line). Two gray lines for events no. 2 and 8 document $L A B$ and asthenosphere. The lowest velocities were found for event no. 4 in the Caledonides and in the northern Baltic Shield. Model for event no. 1 shows a low velocity zone in the lower lithosphere of the southern Baltic Shield. See text for further discussion.

\section{SED}

$5,699-736,2013$

Seismic LAB or LID? The Baltic Shield case

M. Grad et al.

\section{Title Page}

\section{Full Screen / Esc}

Printer-friendly Version 